\title{
A glance at the chemodiversity of Ocimum species: Trends, implications, and strategies for the quality and yield improvement of essential oil
}

\author{
Tanuja P. Gurav • Bhushan B. Dholakia 1 - Ashok P. Giri $\left.{ }^{(}\right)$
}

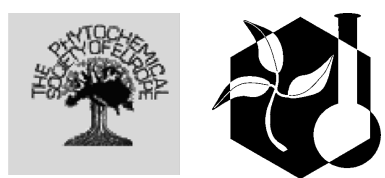

Received: 11 January 2021 / Accepted: 8 July 2021 / Published online: 2 August 2021

(C) The Author(s), under exclusive licence to Springer Nature B.V. 2021

\begin{abstract}
Ocimum species represent commercially important medicinal and aromatic plants. The essential oil biosynthesized by Ocimum species is enriched with specialized metabolites specifically, terpenoids and phenylpropanoids. Interestingly, various Ocimum species are known to exhibit diverse chemical profiles, and this chemical diversity has been at the center of many studies to identify commercially important chemotypes. Here, we present various chemotypes from the Ocimum species and emphasize trends, implications, and strategies for the quality and yield improvement of essential oil. Globally, many Ocimum species have been analyzed for their essential oil composition in over 50 countries. Asia represents the highest number of chemotypes, followed by Africa,
\end{abstract}

Supplementary Information The online version contains supplementary material available at https://doi.org/10.1007/ s11101-021-09767-z.

T. P. Gurav · A. P. Giri · $(\bowtie)$

Plant Molecular Biology Unit, Division of Biochemical Sciences, CSIR-National Chemical Laboratory, Dr. Homi Bhabha Road, Pune, Maharashtra 411008, India

e-mail: ap.giri@ncl.res.in

T. P. Gurav · A. P. Giri .

Academy of Scientific and Innovative Research,

Ghaziabad, Uttar Pradesh 201002, India

B. B. Dholakia · $(\bowtie)$

MBB Department, Tripura University, Suryamaninagar,

Tripura 799022, India

e-mail: bhushan1410@yahoo.com
South America, and Europe. Ocimum basilicum L. has been the most widespread and well-studied species, followed by $O$. gratissimum L., O. tenuiflorum L., $O$. canum Sims, O. americanum and $O$. kilimandscharicum Gürke. Moreover, various molecular reasons, benefits, adverse health effects and mechanisms behind this vast chemodiversity have been discussed. Different strategies of plant breeding, metabolic engineering, transgenic, and tissue-culture, along with anatomical modifications, are surveyed to enhance specific chemotypic profiles and essential oil yield in numerous Ocimum species. Consequently, chemical characterization of the essential oil obtained from Ocimum species has become indispensable for its proper utilization. The present chemodiversity knowledge from Ocimum species will help to exploit various applications in the industrial, agriculture, biopharmaceutical, and food sectors.

Keywords Chemodiversity $\cdot$ Chemotype Essential oil · Metabolic engineering $\cdot$ Ocimum $\cdot$ Specialized metabolites

$\begin{array}{ll}\text { Abbreviations } \\ \text { 4CL } & \begin{array}{l}\text { 4-Coumarate-CoA ligase } \\ \text { CRISPR }\end{array} \\ & \begin{array}{l}\text { Clustered regularly interspaced short } \\ \text { palindromic repeats }\end{array} \\ \text { CVOMT } & \text { Chavicol- } O \text {-methyltransferase } \\ \text { DMAPP } & \text { Dimethylallyl pyrophosphate }\end{array}$




\begin{tabular}{|c|c|}
\hline DXS & $\begin{array}{l}\text { 1-Deoxy-D-xylulose-5-phosphate } \\
\text { synthase }\end{array}$ \\
\hline DXR & $\begin{array}{l}\text { 1-Deoxy-D-xylulose-5-phosphate } \\
\text { reductoisomerase }\end{array}$ \\
\hline EGS & Eugenol synthase \\
\hline EOMT & Eugenol- $O$-methyltransferase \\
\hline HMGR & $\begin{array}{l}\text { 3-Hydroxy-3-methylglutaryl-CoA } \\
\text { reductase }\end{array}$ \\
\hline HPPR & 4-Hydroxyphenylpyruvate reductase \\
\hline IPP & Isopentenyl pyrophosphate \\
\hline MEP & 2-C-Methyl-D-erythritol-4-phosphate \\
\hline MIC & Minimum inhibitory concentration \\
\hline MVA & Mevalonic acid \\
\hline PAL & Phenylalanine ammonia-lyase \\
\hline $\mathrm{TF}$ & Transcription factor \\
\hline TPS & Terpene synthase \\
\hline VOC & Volatile organic compound \\
\hline
\end{tabular}

\section{Introduction}

Among the diverse specialized metabolites biosynthesized in the plant kingdom, volatile organic compounds (VOCs) constitute plant-derived essential oils. They are secreted and stored in different specialized structures, such as intra-cytoplasmic oil bodies, ducts and cavities, glandular trichomes, and osmophores (Jacobowitz and Weng 2020; Rehman et al. 2016). Ocimum genus, which belongs to the Lamiaceae family, includes highly aromatic and essential oilbearing plants with a pantropical distribution ( $\mathrm{Li}$ et al. 2016; Suddee et al. 2005). According to World Flora Online, 66 Ocimum species have been reported until now (http://www.worldfloraonline.org). However, only a few species, such as Ocimum basilicum Linnaeus (L.), O. gratissimum L., O. tenuiflorum L., $O$. canum Sims, $O$. americanum L. and $O$. kilimandscharicum Gürke have been predominantly valued for their phytopharmaceuticals, aroma and flavors. These Ocimum species are endowed with enormous phytochemical diversity. The essential oil of Ocimum species is a complex mixture of odoriferous VOCs. It has extensive applications in the culinary, cosmetics, medicinal, flavor, fragrance, perfumery, nutraceutical, and toiletry industries (Pandey et al. 2014; Singh et al. 2015).

Different tissues of Ocimum species are utilized in fresh, dried, frozen form or distilled essential oil. The
French, Greek, Italian, and Mexican cuisines include mainly fresh leaves of Ocimum species due to their unique aroma. Such fresh aromatic leaves are also suited as flavorings or spices in sauces, stews, salads, and decorations. It can be applied in other food preparations, such as meat, fish, butter, cheese, and beverages (Bown 2001; Meyers 2003; Piva et al. 2021), while essential oil is employed as a food preservative and flavoring agent (Li and Chang 2016). The nanocomposite film prepared from $O$. basilicum seed mucilage can be used for food packaging (Rohini et al. 2020). Further, the essential oil of O. basilicum has been applied to prepare edible coating and food packaging system to increase food shelf-life (Amor et al. 2021; Mohammadi et al. 2021). The various fragrant compounds from Ocimum species essential oil have found utility in personal care products like soaps, mouthwashes, perfumes, hair care, and dental products (Tucker and DeBaggio 2000). Over the years, Ocimum species have been traditionally exploited to treat various ailments in Indian Ayurveda and traditional African, Chinese and European medicine. Several species of the Ocimum genus possess multiple pharmacological properties, e.g., in vitro antimicrobial, antiviral, antimalarial activities and in vivo analgesic, anti-inflammatory, antidiarrhoeal, antidiabetic, anticancer, radiation protective, anti-hyperlipidemic activities, etc. (Ali et al. 2021; Pandey et al. 2014; Purushothaman et al. 2018; Santos et al. 2021; Singh and Chaudhuri 2018; Singh et al. 2015, 2016), whereas essential oil is valued in aromatherapy (Li and Chang 2016). On the other hand, silver and copper nanoparticles synthesized using aqueous leaf extract of $O$. americanum have shown therapeutic properties, including in vitro antibacterial, anticancer and catalytic properties, which can be used for photocatalytic dye degradation (Manikandan et al. 2021a, b). Recently, a molecular docking study showed that apigenin, oleanolic acid and ursolic acid from $O$. basilicum are potential inhibitors of chymotrypsin-like protease of severe acute respiratory syndrome coronavirus (SARS-CoV2) and could be effective in the treatment of coronavirus disease (COVID-19) (Matondo et al. 2021). Moreover, the hydrogel obtained from $O$. basilicum seeds paves the way in the biomedical field for targeted drug delivery and sustained drug release (Lodhi et al. 2020). Apart from this, $O$. basilicum leaf extract has been utilized for preparing mosquito repellent fabrics (Kantheti 
et al. 2020). Additionally, pesticidal activities like fungicidal, nematicidal, larvicidal, insecticidal, trypanocidal, etc., are exhibited by Ocimum species essential oil and their organic or aqueous extracts (Bhavya et al. 2021; Chowdhary et al. 2018; Singh et al. 2014). Furthermore, several Ocimum species have phytoremediation potential for the removal of toxic compounds, such as pesticides (Ramírez-Sandoval et al. 2011), organic dyes (Dada et al. 2020), crude oil (Choden et al. 2021) and heavy metals from soil (Lakshmanraj et al. 2009). Also, bioremediation of heavy metals like copper and chromium is facilitated by $O$. basilicum seeds (Gupte et al. 2012; Melo and D'Souza 2004). Ocimum basilicum seeds have been used as an effective coagulant for the treatment of textile and paper recycling waste water (Mosaddeghi et al. 2020; Shamsnejati et al. 2015).

The promotion of organic, natural, and green consumerism has led to an increased demand for plant-based products. Meanwhile, natural plant products have globally maintained their place in the market under competition from synthetic compounds. Subsequently, plant-derived essential oils are gaining ground despite the availability of synthetic substitutes of essential oils (Khan 2018). It is estimated that the market of Ocimum species essential oil will grow by 186.5 million USD from 2019 to 2023, with an 8\% compound annual growth rate, and Europe will account for the largest market share (https://www. technavio.com/report/global-basil-essential-oil-

market-industry-analysis). Overall, with such a huge market potential, essential oil of Ocimum species is of great economic importance for the developing countries in terms of foreign exchange revenue.

Based on the occurrence of one or more major chemical compounds above a fixed threshold level of relative concentration in the essential oil, several chemotypes have been identified from Ocimum species (Kumar et al. 2019; Simon et al. 1990; Varga et al. 2017). Previously, Grayer et al. (1996) had proposed to describe the chemotype(s) based on all the major compounds constituting greater than $20 \%$ of the total essential oil, while many researchers have now considered compounds above 10\% (Varga et al. 2017). Subsequently, Holm and Hiltunen (1999) have summarized the data on Ocimum species chemotypes until 1999. To the best of our knowledge, no such attempt was made summarizing all available chemotype data from Ocimum species till now. Hence, we explore the existing chemodiversity from essential oil of Ocimum species with potential causes, mechanisms, and the role behind such vast diversity. Additionally, various biotechnological approaches are discussed that can be employed for the chemotypic improvement with better essential oil yield and composition in Ocimum species.

\section{Essential oil and chemical composition of Ocimum species}

The essential oil of Ocimum species, also commonly known as basil oil, is biosynthesized and stored in a specific structure called glandular trichomes present on leaf, stem, and flower (Maurya et al. 2019; Werker et al. 1993). It is made up of secretory cell(s) containing the enzymatic machinery for essential oil biosynthesis and an oil sac for storage. There are two types of glandular trichomes, viz, capitate and peltate, which can be distinguished based on their size and number of the secretory cells (Werker et al. 1993). The essential oil can be obtained from the fresh, semi-dry, or dry aerial plant tissues at the flowering stage by steam distillation or hydro-distillation. The supercritical fluid extraction method is also used to avoid the loss of top notes from the essential oil during the distillation (Occhipinti et al. 2013). Interestingly, in several cases, the essential oil distilled solely from the flowers is superior in chemical composition and thus, of high market value. The essential oil content in leaves of Ocimum species generally varies from 0.5 to $1.4 \%$. However, the composition of essential oil, its yield, and the content varies according to many factors, such as the variety, developmental stage, harvesting season, distillation method, geographical region, and climatic conditions of the plant used (Verma et al. 2013). The specialized metabolites like monoterpenoids, sesquiterpenoids, and phenylpropanoids majorly constitute the essential oil (Pandey et al. 2014). Their analysis and characterization from essential oil is conventionally carried out by gas chromatographymass spectrometry and recently with advanced liquid chromatography-mass spectrometry.

From a biosynthetic point of view, terpenoids are biosynthesized by the condensation of two isoprene precursors, isopentenyl pyrophosphate (IPP) and dimethylallyl pyrophosphate (DMAPP). These are derived from the mevalonic acid (MVA) pathway localized in the cytosol or 2- $C$-methyl-D-erythritol-4- 
phosphate (MEP) pathway localized in the plastid (Vranová et al. 2013; Zhou and Pichersky 2020). The principal monoterpenoids reported from Ocimum species essential oil are camphor, 1,8-cineole, citronellal, geranial, geraniol, linalool, limonene, neral, ocimene, terpinene, and thymol. Similarly, the major sesquiterpenoids are bisabolene, bergamotene, caryophyllene, cadinol, farnesene, and germacrene. Till now, more than 100 monoterpenoids and over 135 sesquiterpenoids have been identified from the essential oil of several Ocimum species with diverse applications (Tables 1 and 2). The phenylpropanoids are derived from the amino acid phenylalanine, which is in a few steps converted to the 4-coumaroyl-CoA (Anand et al. 2016; Iijima et al. 2004). Later, coniferyl and coumaryl alcohols derived from 4-coumaroyl$\mathrm{CoA}$ act as precursors for biosynthesis of various phenylpropanoid derivatives (Gang et al. 2001; Lavhale et al. 2018, 2021; Liu et al. 2015). About 10 phenylpropanoids have been reported from essential oil of Ocimum species, and among them, eugenol, methyl cinnamate, methyl chavicol, and methyl eugenol occur predominantly (Table 3 ). The structures of the main terpenoids and phenylpropanoids present in the essential oil from various Ocimum species are depicted in Fig. 1. These metabolites have culinary, industrial, consumer and therapeutic applications (Tables 1, 2, and 3).

\section{Chemotypes reported from various Ocimum species and their hybrids}

The chemistry of $O$. basilicum is most studied because of its worldwide distribution. Among the published reports on the chemical diversity in Ocimum species, most of the reports (43\%) are available on O. basilicum, followed by $O$. gratissimum (16\%), while minimum reports $(0.3 \%)$ are available on $O$. adscendens Willdenow (Willd.), O. urticifolium Roth, and O. suave Willd. (Fig. 2). Globally, 16 Ocimum species have been analyzed for their essential oil composition across 55 countries. Subsequently, nine to ten Ocimum species cover the most chemotypes from Asia, followed by Africa, South America, and Europe (Fig. 3). Looking at the countrywide distribution pattern, India has 75 different chemotypes from eight Ocimum species, while 56 different chemotypes are reported from Brazil from eight
Ocimum species. Ocimum basilicum has been the most widespread and studied species, followed by O. gratissimum, O. tenuiflorum, O. canum, O. americanum, and $O$. kilimandscharicum. Overall, a total of 76 chemotypes have been identified from $O$. basilicum, indicating the enormous chemodiversity, while others like $O$. gratissimum and $O$. tenuiflorum have 30 and 24 chemotypes, respectively (Fig. S1). The species $O$. basilicum, O. americanum, O. gratissimum, O. kilimandscharicum, O. minimum L., O. suave, and O. campechianum Miller (Mill.) have shown a combination of monoterpenoid- and phenylpropanoid-rich chemotypes. The phenylpropanoid-rich chemotypes are exclusively reported from O. tenuiflorum, O. selloi Bentham (Benth.), $O$. micranthum Willd., O. adscendens, O. urticifolium Roth, and O. ciliatum Hornemann (Hornem.) species, while $O$. canum has monoterpenoid-rich chemotypes (Fig. S2). Furthermore, the species-wise predominant occurrence of specialized metabolites in the essential oil of different Ocimum species is shown in Fig. 4. Additionally, species-wise chemotype details are highlighted in the following section.

Various chemotypes from $O$. basilicum cover its many subspecies and varieties that can be distinguished based on phenotype and chemical composition. The predominantly occurring chemotypes of $O$. basilicum essential oil are citral (Padalia et al. 2017), methyl chavicol (Olugbade et al. 2017), linalool, methyl cinnamate/linalool (Raina and Gupta 2018), linalool/1,8-cineole (da Costa et al. 2016), linalool/ eugenol (Carović-Stanko et al. 2010b), linalool/ methyl chavicol (Rawat et al. 2017), methyl chavicol/linalool (Maurya and Sangwan 2019), etc. (Table S1). Some of the uncommon chemotypes reported for $O$. basilicum essential oil are citral/ spathulenol (Vieira and Simon 2006), limonene/borneol (Ademiluyi et al. 2016), linalool/epi-bicyclosesquiphellandrene (Antić et al. 2019), borneol/ $\beta$ ocimene (Farhang et al. 2014), menthone/methyl chavicol (Hassanpouraghdam et al. 2010), $\alpha$-muurolol $/ \gamma$-muurolene (Amaral-Baroli et al. 2016), etc. (Table S1). The major essential oil chemotypes from O. tenuiflorum are characterized by a large amount of eugenol (23-77\%) and methyl eugenol (36-93\%) (Raina et al. 2013; Raina and Misra 2018). Moreover, eugenol/ $\beta$-caryophyllene, eugenol/methyl eugenol (Rana and Blazquez 2015), methyl eugenol/ $\beta$ caryophyllene (Piras et al. 2018), etc., occur as major 


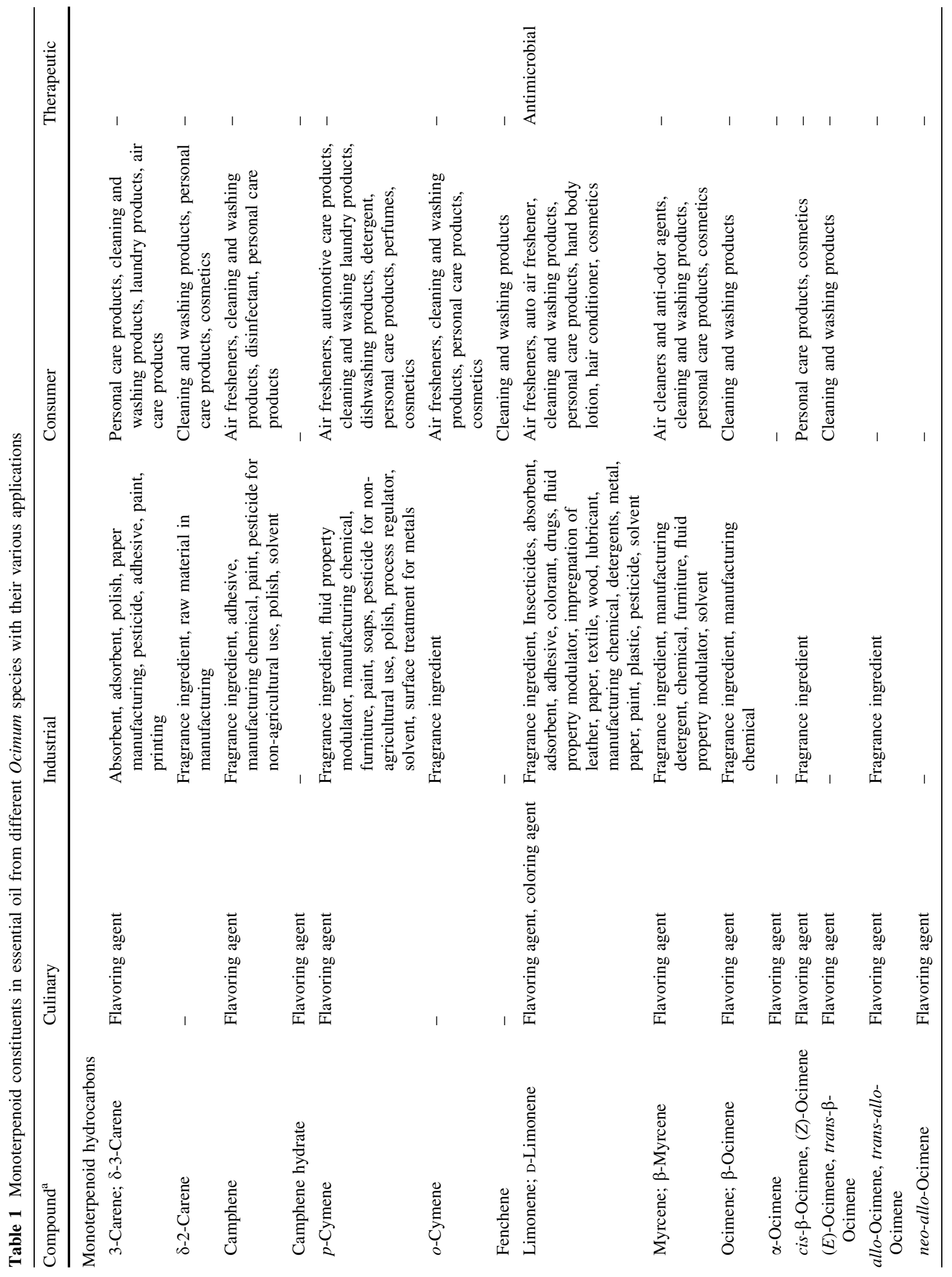




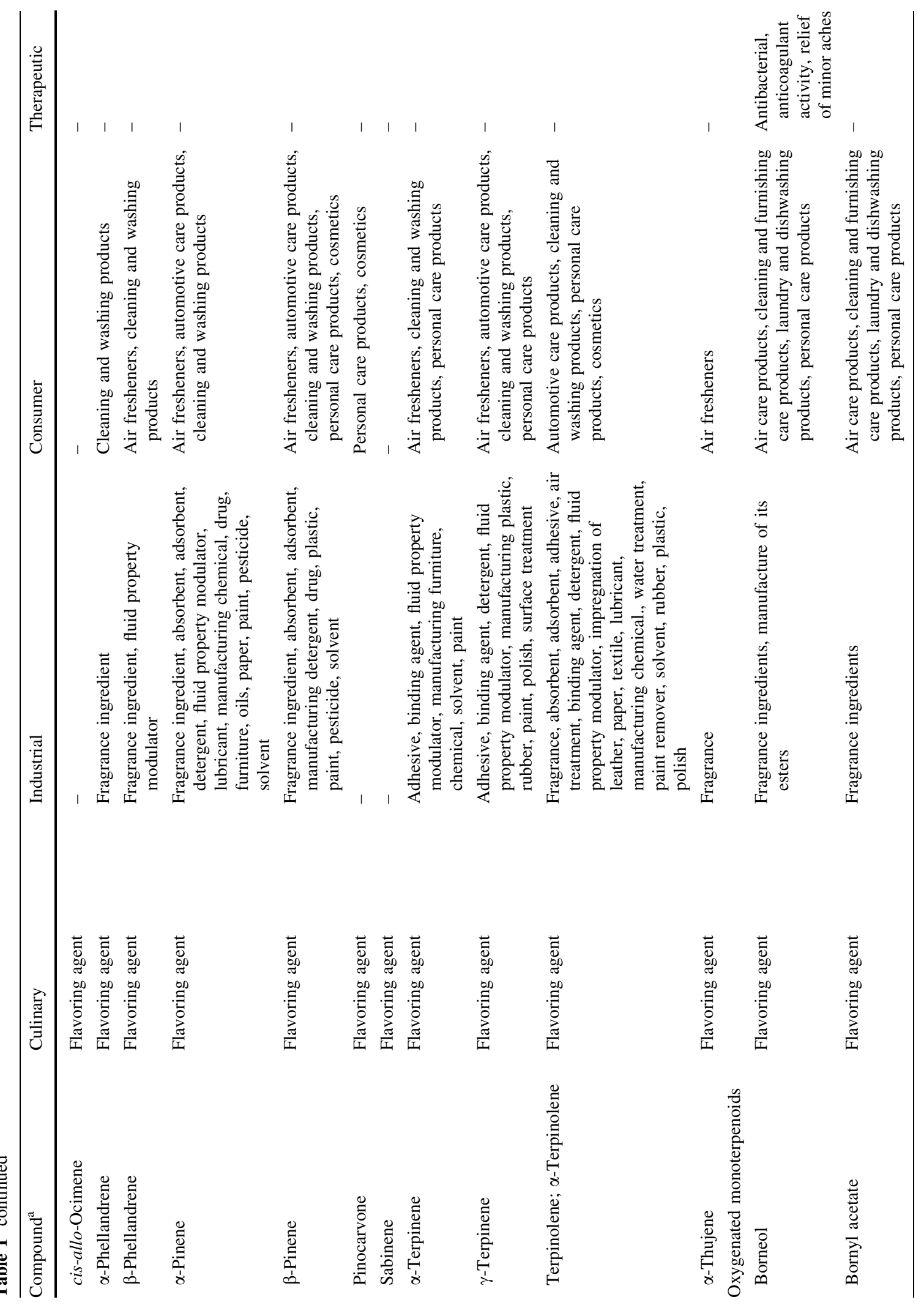




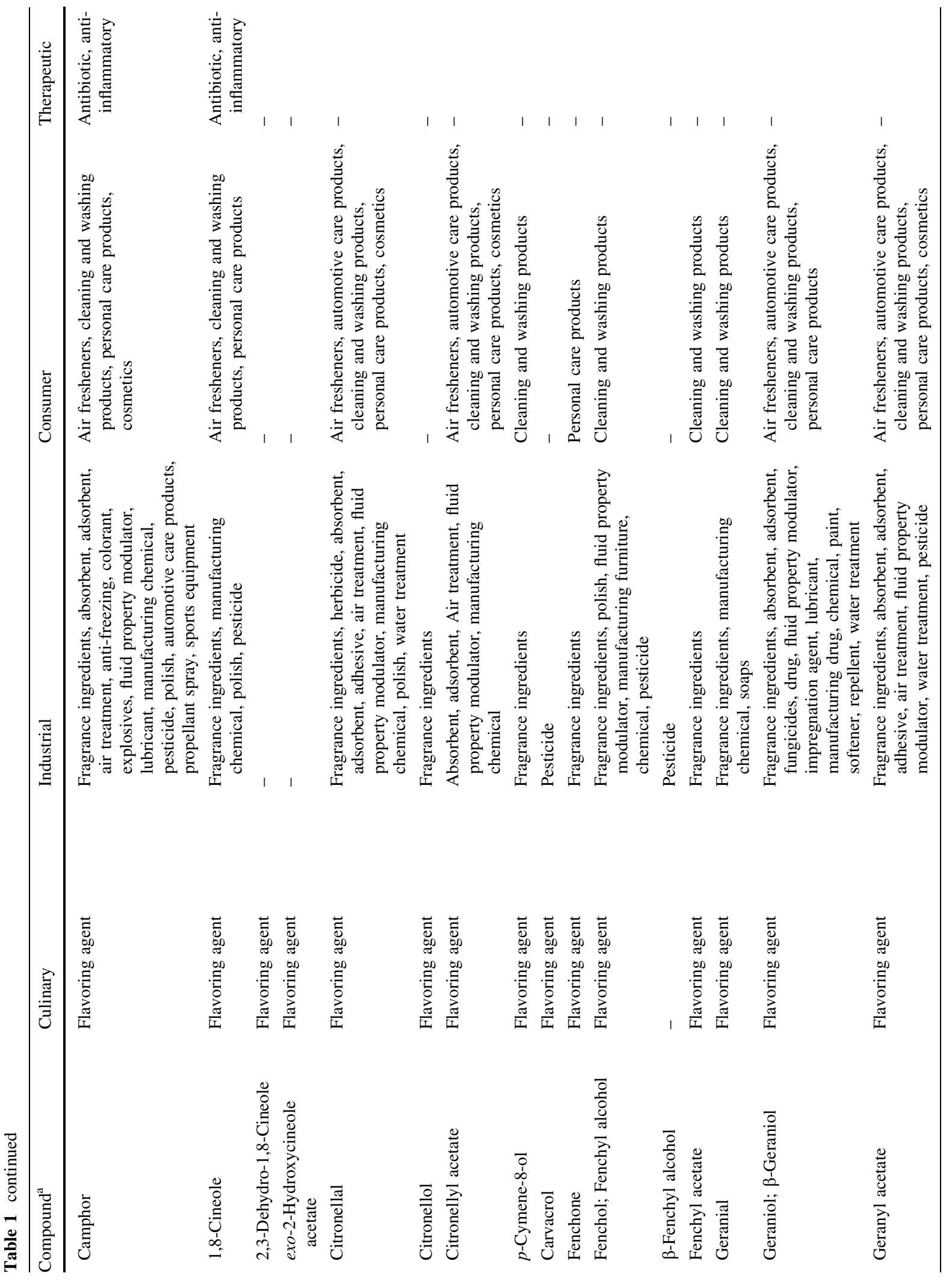




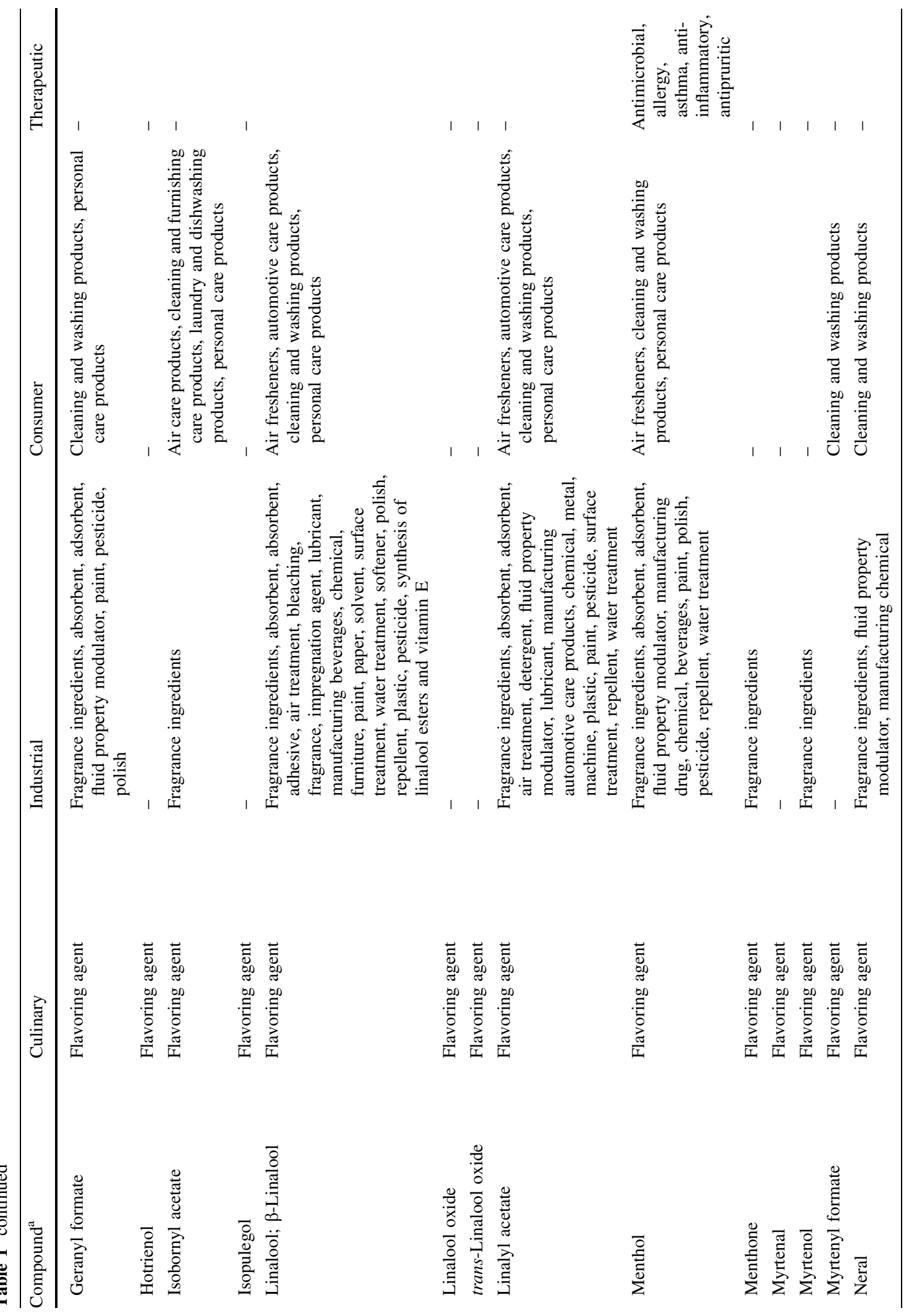




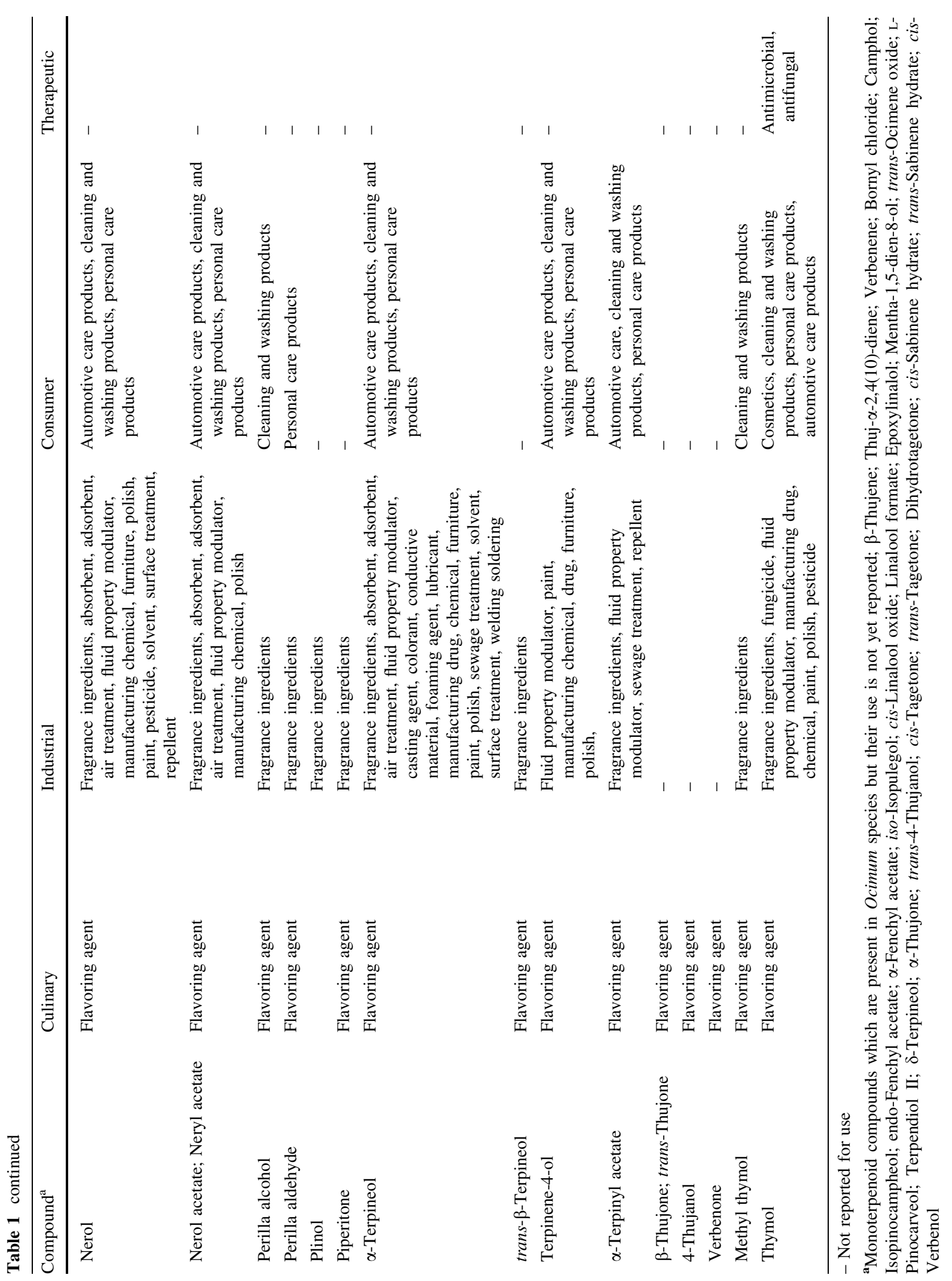


chemotypes, while exceptional chemotypes $\beta$-elemene/ $\beta$-caryophyllene (Kitchlu et al. 2013), 1,8cineole/ $\beta$-bisabolene (Carović-Stanko et al. 2011), eugenol/ $\alpha$-cubebene, eugenol/ $\alpha$-humulene (Saran et al. 2017), etc., have also been detected in $O$. tenuiflorum (Table S2). O. americanum essential oil can be represented by camphor (Raina and Misra 2018), camphor/limonene (Verma et al. 2016), citral (Mondello et al. 2002), linalool (Olugbade et al. 2017), methyl cinnamate (Vieira and Simon 2006), methyl chavicol/linalool (Singh et al. 2013), etc., as main chemotypes (Table S3). However, anisole, $\beta$-bisabolene/1,8-cineole (Vieira and Simon 2006), eugenol/ $\beta$-bisabolene (Singh et al. 2013), caryophyllene/ methyl eugenol (Viña and Murillo 2003), etc., chemotypes occur rarely in $O$. americanum (Table S3). In $O$. gratissimum, thymol (Olugbade et al. 2017), thymol/ $p$-cymene (Benelli et al. 2019), thymol $/ \gamma$-terpinene (Hzounda et al. 2016), eugenol (Dambolena et al. 2010), eugenol/1,8-cineole (Rao et al. 2011), eugenol/ thymol (Kumar et al. 2019), etc., are major chemotypes, while eugenol/(Z)- $\beta$-ocimene (Santana et al. 2014), eugenol/ $\alpha$-humulene (Dambolena et al. 2010), trans-methyl isoeugenol/cis-ocimene (Rana and Blazquez 2015), eugenol/ $\alpha$-bergamotene (Carović-Stanko et al. 2011), eugenol/camphor (Rao et al. 2011), etc., are the uncommon chemotypes (Table S4). Apart from this, O. canum essential oil is enriched with different chemotypes such as linalool (Yayi et al. 2001), 1,8cineole/ $\beta$-pinene (Hüe et al. 2015), camphor/limonene (Selvi et al. 2015), methyl eugenol/1,8-cineole (Rubiyanto et al. 2015), thymol/ $p$-cymene (da Silva et al. 2018), carvacrol/p-cymene (Mith et al. 2016), etc. (Table S5). Similarly, 1,8-cineole/ $\beta$-caryophyllene (Carović-Stanko et al. 2011) and methyl eugenol (Zoghbi et al. 2007) are detected as main chemotypes from the $O$. campechianum (Table S5).

Camphor is the main chemotype of the essential oil from O. kilimandscharicum, with concentration ranging from 16 to 70\% (Carović-Stanko et al. 2011; Padalia and Verma 2011; Raina and Gupta 2018). Similarly, camphor/1,8-cineole (Carović-Stanko et al. 2010b), camphor/limonene (Singh et al. 2011) occur frequently, while camphor/ $\beta$-selinene (Rana and Blazquez 2015), eugenol/(Z)- $\beta$-ocimene (Kunwar et al. 2018), methyl eugenol $/ \gamma$-cadinene (Lawal et al. 2014), etc., are the uncommon chemotypes reported for O. kilimandscharicum (Table S6). Different chemotypes of the least studied Ocimum species such as $O$. minimum, $O$. africanum Loureiro (Lour.), $O$. ciliatum, $O$. suave, $O$. lamiifolium Hochstetter (Hochst.) ex Benth., O. selloi, O. micranthum, O. adscendens and $O$. urticifolium have been listed in Tables S7 and S8.

Additionally, few reports are from different intraand inter-specific Ocimum species hybrids (Table S9). These studies suggest that intra- and inter-specific hybridization, in general, can generate new spectra of VOCs in hybrids that may not be present in the parental species (da Costa et al. 2014). For instance, linalool/methyl chavicol chemotype has been identified from the intraspecific hybrids between various $O$. basilicum cultivars. Further, hybridization also favored the generation of camphor, neral, geranial, $\beta$ selinene, bicyclogermacrene, $(E)$-caryophyllene, and methyl chavicol (da Costa et al. 2016). Similarly, $O$. citriodorum Visiani (Vis.) is an interspecific hybrid between $O$. basilicum and $O$. canum with a strong lemony scent. The essential oil from this hybrid is incredibly rich in citral, comprising a mixture of geranial (31-46\%) and neral (21-35\%) (CarovićStanko et al. 2010b; Raina and Gupta 2018) (Table S9). Recently, natural hybridization between terpenoid-rich $O$. kilimandscharicum and phenylpropanoid-rich $O$. basilicum has led to two novel hybrids with the chemotype of methyl chavicol/ $\beta$ linalool (Gurav et al. 2020) (Table S9).

\section{Potential causes of the vast chemodiversity in Ocimum species}

The chemical composition at any developmental stage of the plant is determined by its genotype along with differential expression and regulation of genes involved in the biosynthetic pathways (Gonçalves and Romano 2013; Singh et al. 2015) (Fig. 5). For instance, $O$. gratissimum and $O$. tenuiflorum both are phenylpropanoid-rich species; however, higher expression of EUGENOL-O-METHYLTRANSFER$A S E$ (EOMT) in O. tenuiflorum leads to more methyl eugenol. As expected, lower EOMT expression results in eugenol-rich chemotype in $O$. gratissimum (Anand et al. 2016). Further, the genetic regulation of specialized metabolic pathways at the post-transcriptional and post-translational levels is considerably responsible for chemodiversity (Fig. 5). For example, a higher transcript and protein level of $\mathrm{CHAVICOL-O}$ - 


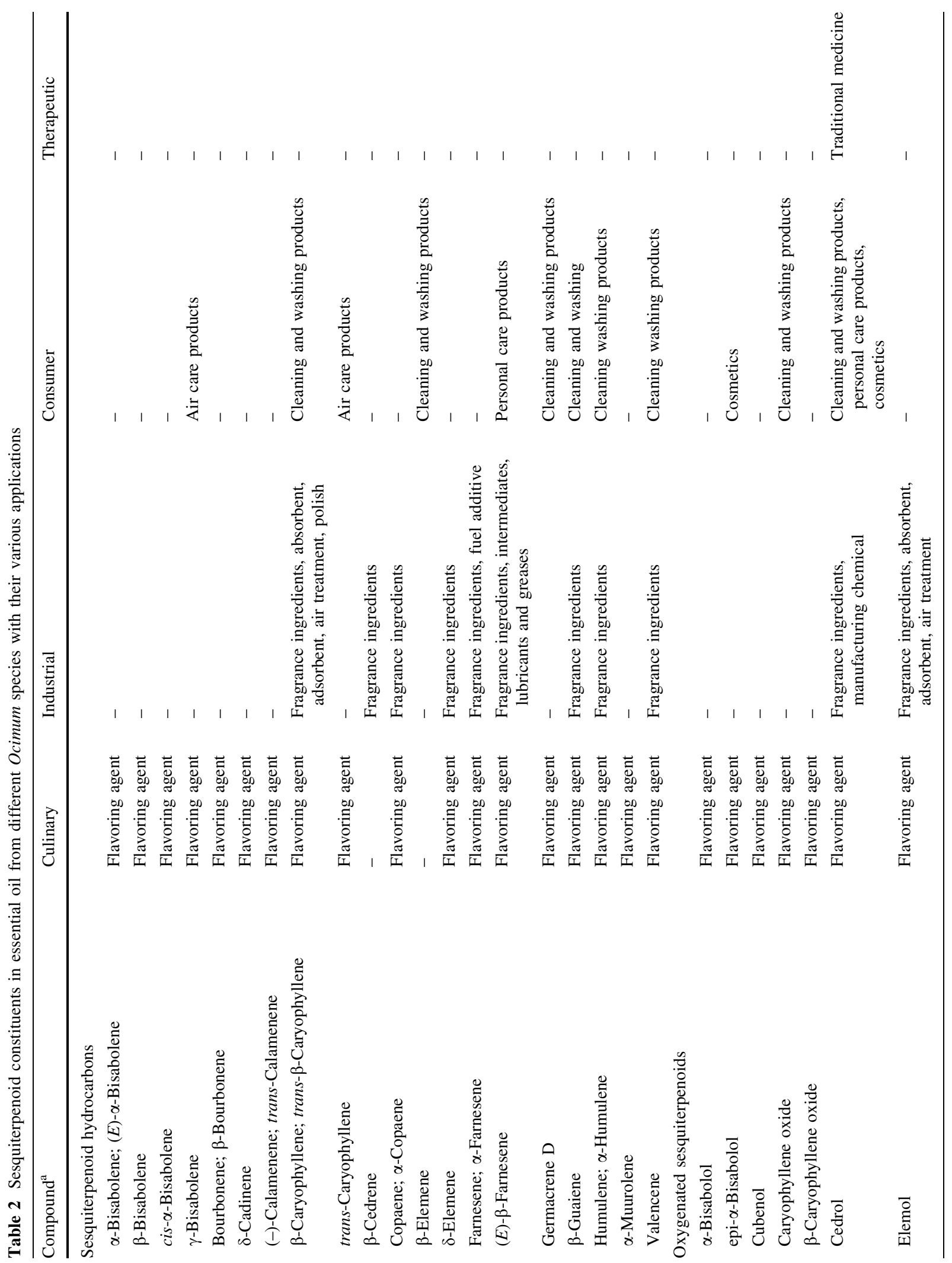




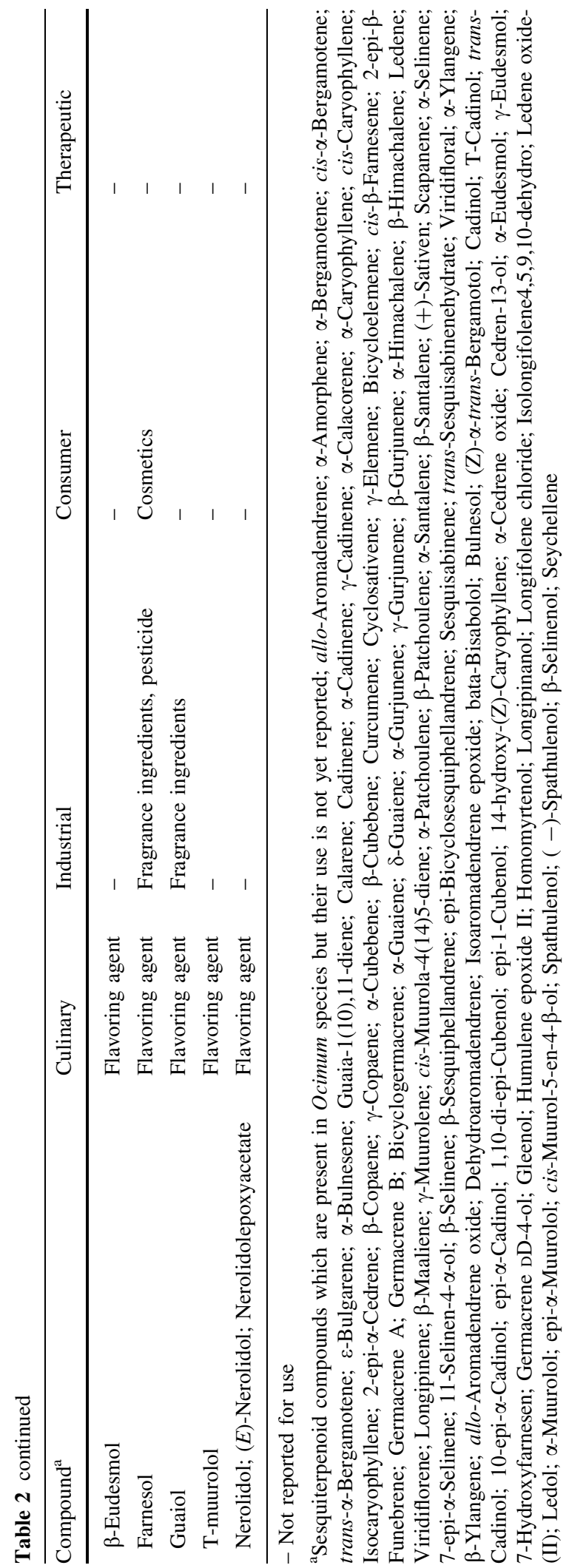

METHYLTRANSFERASE (CVOMT) was observed in $O$. basilicum (line SD). However, ubiquitination of CVOMT has led to a reduction in enzyme activity, and thus, it decreased methyl chavicol content in $O$. basilicum (line SD). Alternatively, in the absence of this ubiquitination, O. basilicum (line EMX-1) showed higher CVOMT activity with high methyl chavicol content (Xie et al. 2008). The vast array of terpenoids in the Ocimum species is biosynthesized by different terpene synthases (TPSs) that have an exclusive ability to catalyze multiple product formation using a single substrate (Iijima et al. 2004) (Fig. 5). Additionally, both molecular and environmental factors affect chemical composition (Verma et al. 2013).

The existence of different chemotypes in Ocimum species could also be attributed to cross-pollination leading to intra- and inter-specific hybridization, resulting in higher variation in the chemical profiles (Gurav et al. 2020; Varga et al. 2017). Other factors, such as plant habit, can also influence specialized metabolism. For instance, the popular sanctum group of Ocimum species (O. tenuiflorum, O. gratissimum, $O$. viride Willd., $O$. suave and $O$. carnosum) prominently harbors phenylpropanoid biosynthesis because of perennial woody habit. The possible explanation for this is phenylpropanoid biosynthetic pathway generates monolignol alcohols required for lignin biosynthesis. In contrast, the basilicum group of Ocimum species $(O$. canum, O. basilicum, O. americanum, and O. kilimandscharicum) harbors terpenoid biosynthesis because of the annual herbaceous habit (Khosla 1995). Also, natural evolutionary events, polyploidy, and selective breeding can play a significant role in chemical diversification as observed in different Ocimum species (Carović-Stanko et al. 2010a; Iijima et al. 2004). Similarly, the occurrence of either phenylpropanoid- or terpenoid-rich Ocimum species may be attributed to the diversification of pathways during the evolution (Singh et al. 2015). Thus, looking at such a massive chemodiversity, the next obvious point arises about why plant generates them?

\section{Multiple benefits of chemodiversity to Ocimum species}

Albeit humans have explored plant-derived aromatic compounds for their benefits, plants do not produce 


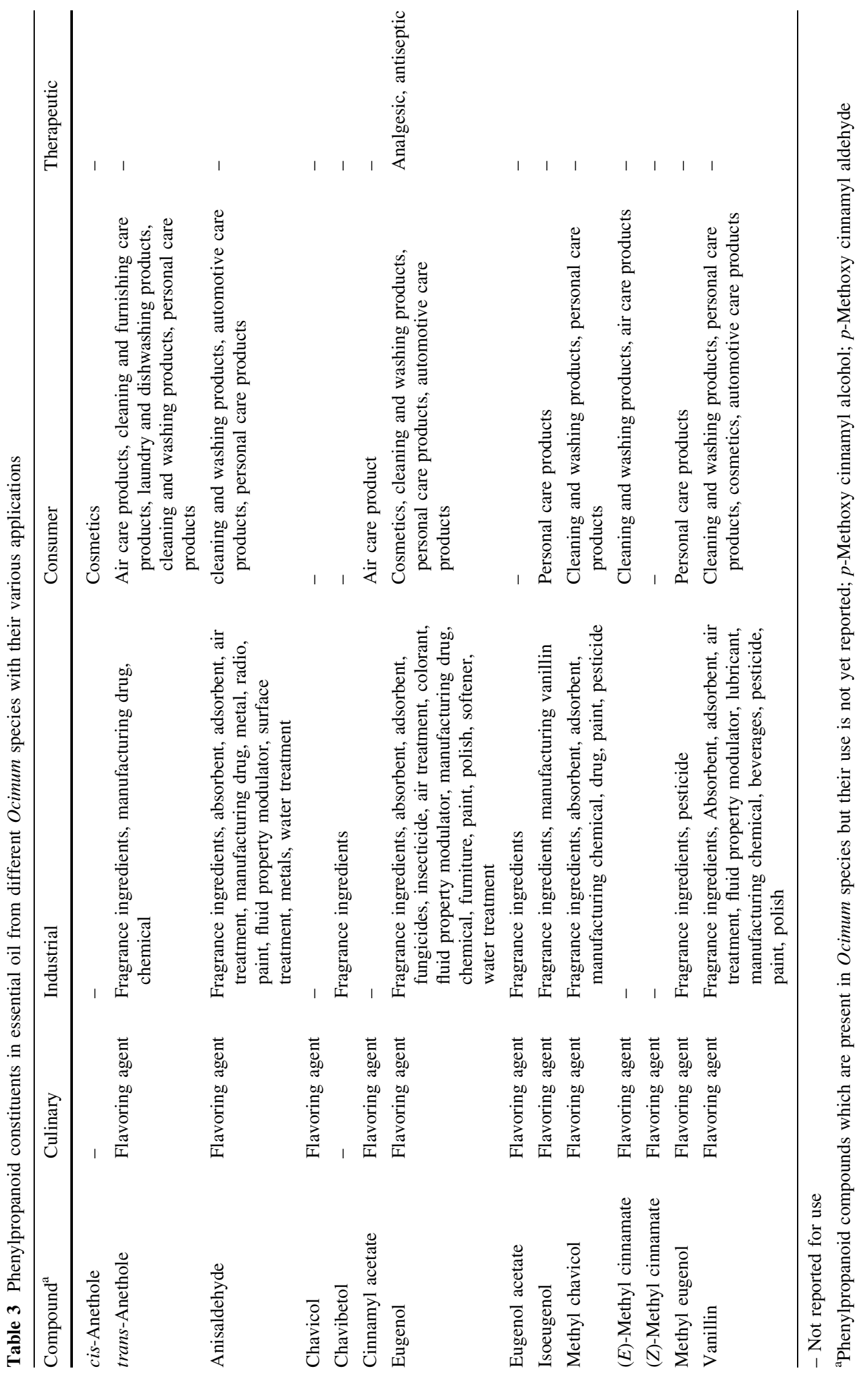




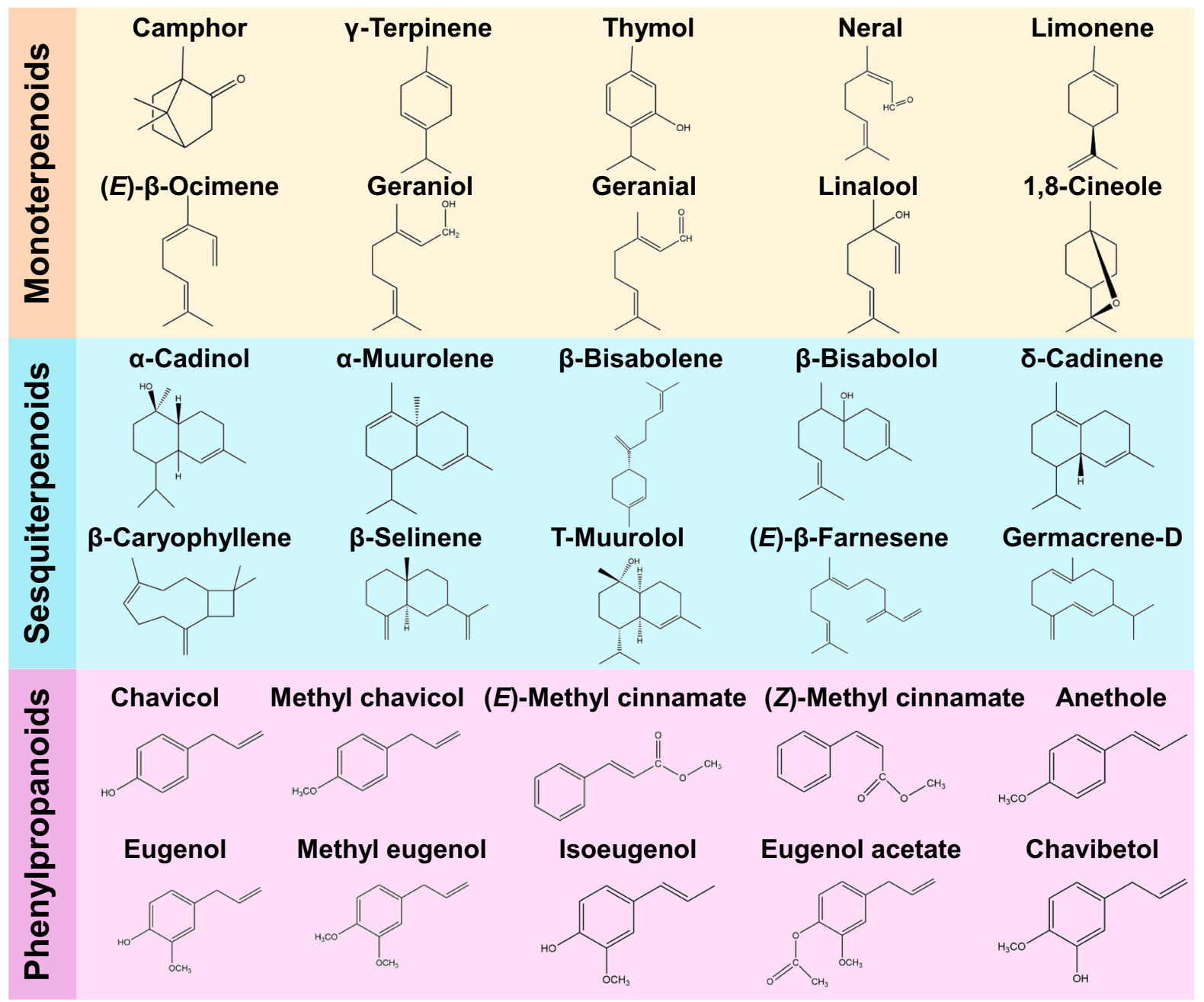

Fig. 1 Major specialized metabolites of monoterpenoid, sesquiterpenoid and phenylpropanoid classes reported from the essential oil of various Ocimum species

them for such purposes. As plants are sessile, they communicate with the surrounding environment using a chemical language by emitting diverse VOCs. These are typically lipophilic compounds that evaporate into the atmosphere because of high vapor pressure (Dudareva et al. 2013). Plant-derived VOCs function in arrays of ecological contexts, such as plant reproduction, protection, communication, and adaptation to abiotic stresses (Dudareva et al. 2013; Vivaldo et al. 2017; Vranová et al. 2013) (Fig. 6). Plants that cannot self-pollinate are dependent on pollinators for their reproductive success (Dudareva and Pichersky 2000). Plant VOCs serve as an attractant for various pollinators like beetles, moths, bees, etc. For example, compounds like linalool, methyl eugenol attract pollinators, whereas esters released by the ripened fruit attract seed-dispersing agents (Gang 2005; Raguso and Pichersky 1995). As O. basilicum is entomophilous, during flowering, it benefits the other neighboring plant by increasing the frequency of pollinator visits (Jiang et al. 2016). In response to the damage or herbivory, plants release VOCs to deter or repel the insect or animal herbivores (Kessler and Baldwin 2002). Furthermore, for their self-defense, plant VOCs aid in recruiting various parasitic or predatory insects that are enemies of attacking herbivores (Dicke and van Loon 2000; Shiojiri et al. 2002). Some of the Ocimum species can be used as a companion plant with crops for biological control of pests, such as aphids, beetles, moths and whiteflies, as 
Fig. 2 The percentage distribution of articles on the chemical diversity of different Ocimum species over the last few decades. The maximum reports emphasized the chemical composition of $O$. basilicum owing to its commercial importance, followed by O. gratissimum

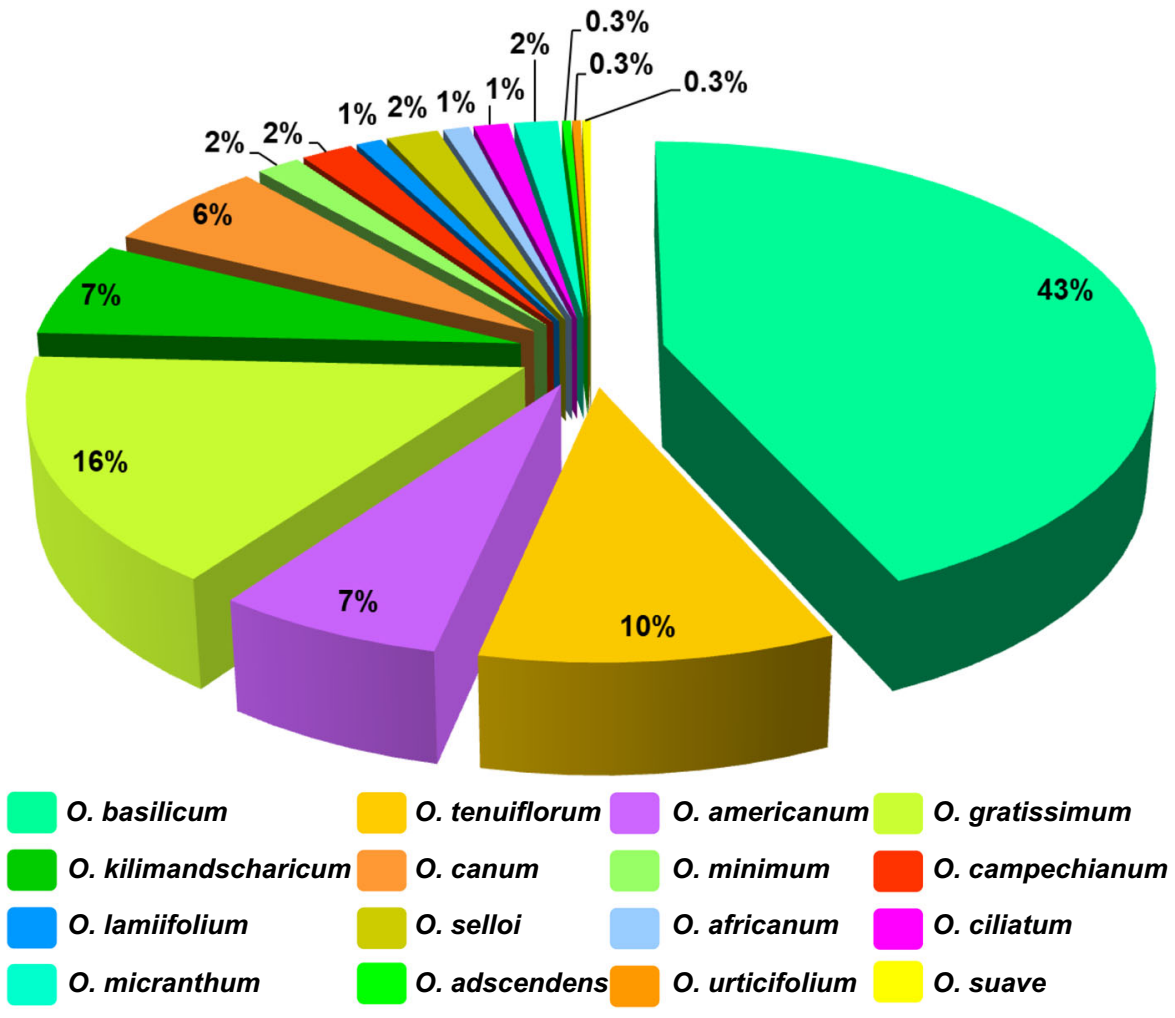

well as for attracting predatory insects. For instance, Amaranthus hybridus plant had lower aphid infestation when surrounded with either $O$. basilicum or O. gratissimum than alone (Yarou et al. 2020). Similarly, Aphis citricola aphid abundance was decreased by $38 \%$, and the number of its natural enemies also increased when apple trees intercropped with O. basilicum (Song et al. 2013). Also, the presence of $O$. basilicum and $O$. gratissimum in the vicinity of the tomato reduced oviposition of leafminer Tuta absoluta on tomato plants (Yarou et al. 2018). In another study, $O$. basilicum attracted the generalist predatory insect green lacewing Ceraeochrysa cubana and benefited the larval and adult survival (Batista et al. 2017). Moreover, many volatile metabolites possess antibacterial and antifungal activities that may protect the plant from pathogens (Dicke and Baldwin 2010; Quintana-Rodriguez et al. 2018). For example, methyl chavicol-rich essential oil of $O$. ciliatum has been shown to possess in vitro antibacterial activity against phytopathogens of genus Xanthomonas, Pseudomonas, and Agrobacterium (minimum inhibitory concentration $(\mathrm{MIC})=1-6 \mathrm{mg}$ of essential oil $/ \mathrm{mL}$ medium) (Moghaddam et al. 2014). Similarly, methyl chavicol-rich essential oil from $O$. selloi revealed in vitro antifungal activity, by reducing spore germination, against phytopathogenic fungi Colletotrichum gloeosporioides (MIC $\geq 1000 \mathrm{ppm}$ ) and Moniliophthora perniciosa $(\mathrm{MIC}=250-500 \mathrm{ppm})($ Costa et al. 2015), while methyl chavicol (at $1000 \mathrm{ppm}$ ) and linalool (at $300 \mathrm{ppm}$ ) chemotypes of $O$. basilicum reduced the mycelial growth of Botrytis fabae by 78 and $49 \%$, respectively (Oxenham et al. 2005). Upon the herbivore attack, VOCs released by the infested plant may further induce the volatile emission from healthy leaves of the same plant or adjacent unchallenged plants (Baldwin et al. 2006). In Ocimum species, there is no such report of the metabolic priming on the neighboring plant; however, this metabolic priming results in a more rapid and intense defense response that can be mounted by healthy adjacent plants upon any subsequent herbivory attack (Engelberth et al. 2004; Kim and Felton 2013). Plants also compete with other nearby plants because of the allelopathic effect on their germination and growth through VOCs (Romagni et al. 2000). Aqueous leaf extract of $O$. basilicum has been shown to have an inhibitory effect on the growth of weeds, Anagallis 


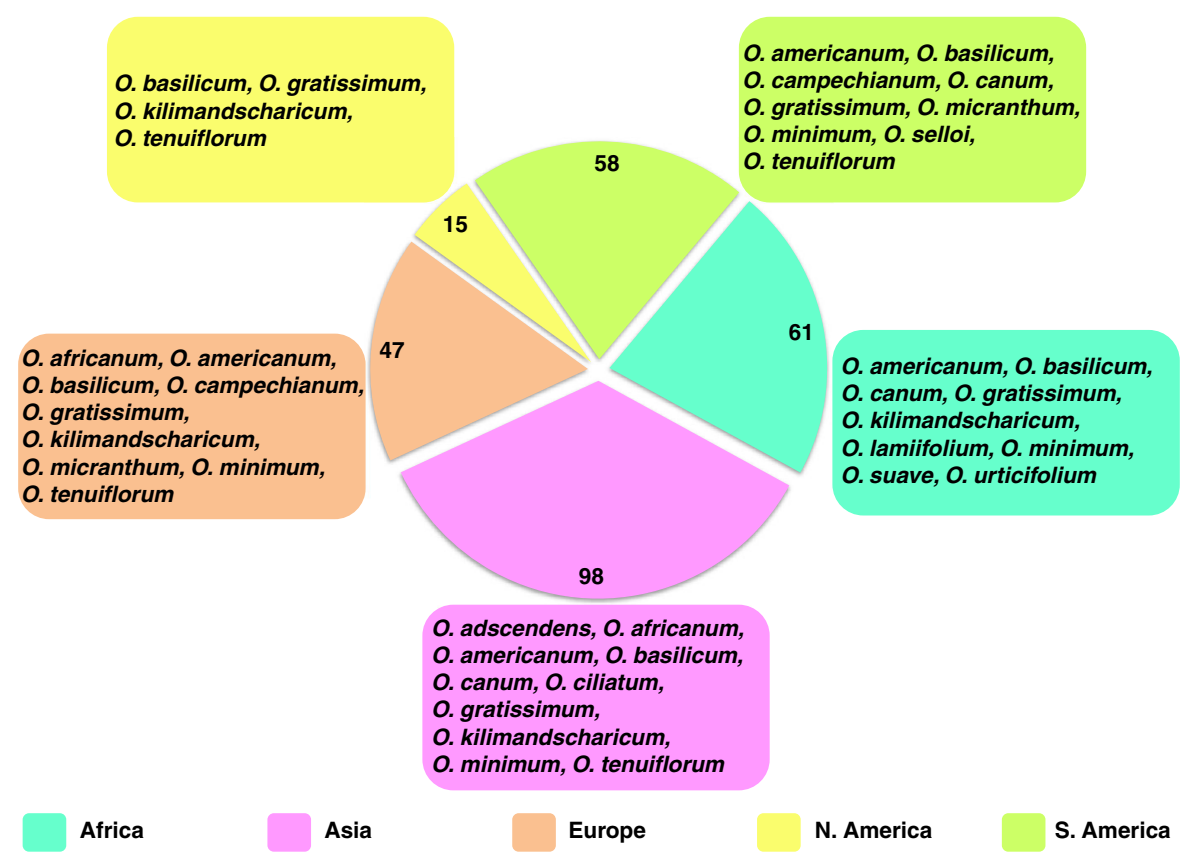

Fig. 3 Distribution of the total number of chemotypes of various Ocimum species reported from global continental regions. The maximum number of chemotypes representing

arvensis and Phalaris minor (El-Rokiek et al. 2018). Moreover, plants throughout their life cycle are exposed to a variety of abiotic stress conditions. Different VOCs can serve as photoprotective, thermotolerant, and antioxidant agents (Fig. 6) by safeguarding plants against light, heat, cold, and oxidative stress conditions (Cofer et al. 2018; Loreto and Schnitzler 2010; Loreto and Velikova 2001). For instance, volatile terpenoids improve plant tolerance to the abiotic stresses by quenching reactive oxygen species (ROS) or stabilizing the cell membrane (Brilli et al. 2019). In O. basilicum, drought stress resulted in the enhanced production of $\alpha$-bergamotene, $\beta$-myrcene, methyl eugenol, and methyl chavicol (Mandoulakani et al. 2017). Similarly, microwave exposure led to higher emission of $\alpha$-bergamotene, 1,8-cineole, caryophyllene oxide, and methyl chavicol (Lung et al. 2016). However, decrease in the eugenol and methyl eugenol levels was observed in $O$. tenuiflorum under cold, drought, flood and salt stress conditions (Rastogi et al. 2019). ten Ocimum species is reported from Asia, followed by nine Ocimum species from Africa and S. America

\section{Potential adverse health effects of specialized metabolites present in Ocimum species}

Though terpenoids and phenylpropanoids have been widely used in various applications, they enter the human body through oral, dermal, and nasal routes. Despite their many health benefits, some specialized metabolites like camphor, methyl eugenol, and methyl chavicol present in the essential oil of Ocimum species could have toxic effects after particular concentrations based on the data from in vivo and in vitro studies in model organisms or cell lines (Bristol 2011; Johnson et al. 2000; Zuccarini 2009) (Table 4). For example, methyl eugenol and methyl chavicol are reported of having genotoxic or carcinogenic potential at specific levels (Table 4). Interestingly, Ocimum species aqueous or organic extracts of a specific tissue or whole plant were found to be less toxic (Table 4). Most of the terpenoids have shown some cytotoxic effects primarily on vital organs, such as the liver, lungs, kidney, and neuronal tissues at higher concentrations when used in pure form. These cytotoxic studies have shown that these terpenoids exert adverse effects by disrupting plasma membrane, producing ROS, impairing 


\begin{tabular}{|c|c|c|}
\hline Monoterpenoids & Sesquiterpenoids & Phenylpropanoids \\
\hline \multirow{4}{*}{$\begin{array}{l}\text { O. basilicum } \\
\text { Borneol, Camphor, 1,8-Cineole, } \\
\text { Citral, Geraniol, Linalool, } \\
\text { Limonene, Linalyl acetate, } \\
\text { Menthone } \\
\text { Bergamotene, Bisabolene, } \\
\text { Bicyclosesquiphellandren, } \\
\text { Cedrene, Cadinol, Farnesene, } \\
\text { Muurolol } \\
\text { Anethole, Eugenol, Methyl } \\
\text { chavicol, Methyl cinnamate, } \\
\text { Methyl eugenol }\end{array}$} & \multirow{2}{*}{$\begin{array}{l}\text { O. gratissimum } \\
\text { Bornyl acetate, 1,8-Cineole, } p \text { - } \\
\text { Cymene, Geraniol, Linalool, } \\
\text { Ocimene, } \gamma \text {-Terpinene } \\
\text { (Z)-a-Bisabolene, a-Bulnesene, } \\
(E, E)-a-\text {-Farnesene, } a-\text {-Humulene } \\
\text { Eugenol, trans-Methyl } \\
\text { isoeugenol, Thymol }\end{array}$} & $\begin{array}{l}\text { O. kilimandscharicum } \\
\text { Camphor, 1,8-Cineole, Linalool } \\
\gamma \text {-Cadinene, } \beta \text {-Selinene } \\
\text { Eugenol, Methyl chavicol, } \\
\text { Methyl eugenol }\end{array}$ \\
\hline & & \multirow{2}{*}{$\begin{array}{l}\text { O. selloi } \\
\text { Linalool } \\
\text { trans-Anethole, Eugenol, Methyl } \\
\text { eugenol, Methyl chavicol }\end{array}$} \\
\hline & \multirow{4}{*}{$\begin{array}{l}\text { O. canum } \\
\text { 1,8-Cineole, Camphor, } p \text { - } \\
\text { Cymene, Limonene, Linalool, } \\
\text { Terpineol } \\
\beta \text {-Pinene } \\
\text { Eugenol, Methyl eugenol, Methyl } \\
\text { chavicol, Thymol }\end{array}$} & \\
\hline & & $\begin{array}{l}\text { O. urticifolium } \\
\beta \text {-Bisabolene }\end{array}$ \\
\hline \multirow{3}{*}{$\begin{array}{l}\text { O. tenuiflorum } \\
\text { 1,8-Cineole, Linalool } \\
\beta \text {-Bisabolene, } \beta \text { - Caryophyllene, } \\
\beta \text {-Elemene } \\
\text { Eugenol, Methyl eugenol }\end{array}$} & & Eugenol \\
\hline & & \multirow{2}{*}{$\begin{array}{l}\text { O. suave } \\
\text { Germacrene-D, Germacrene-B } \\
\text { Methyl eugenol }\end{array}$} \\
\hline & \multirow{2}{*}{$\begin{array}{l}\text { O. campechianum } \\
\text { 1,8-Cineole } \\
\beta \text {-Caryophyllene, Sabinene } \\
\text { Eugenol, Methyl eugenol }\end{array}$} & \\
\hline \multirow{3}{*}{$\begin{array}{l}\text { O. americanum } \\
\text { Camphor, Citral, 1,8-Cineole, } \\
\text { Linalool } \\
\beta \text {-Bisabolene, Caryophyllene } \\
\text { Anisole, Eugenol, Methyl } \\
\text { cinnamate, Methyl chavicol }\end{array}$} & & \multirow{2}{*}{$\begin{array}{l}\text { O. minimum } \\
\text { Geranyl acetate, Linalool } \\
\text { Methyl chavicol, Methyl } \\
\text { cinnamate }\end{array}$} \\
\hline & \multirow{3}{*}{$\begin{array}{l}\text { O. micranthum } \\
\beta \text {-Caryophyllene, }(E) \text { - } \\
\text { Caryophyllene } \\
\text { Eugenol, Methyl cinnamate }\end{array}$} & \\
\hline & & O. africanum \\
\hline \multirow{2}{*}{$\begin{array}{l}\text { O. lamiifolium } \\
\text { Bornyl acetate, } p \text {-Cymene, (Z)- } \beta \text { - } \\
\text { Ocimene } \\
\text { a-Phellandrene, Sabinene }\end{array}$} & & \\
\hline & $\begin{array}{l}\text { O. ciliatum } \\
\text { Citral } \\
\text { Methyl chavicol }\end{array}$ & $\begin{array}{l}\text { O. adscendens } \\
\text { (E)-Caryophyllene } \\
\text { Eugenol }\end{array}$ \\
\hline
\end{tabular}

Fig. 4 Species-wise predominant occurrence of specialized metabolites of monoterpenoid, sesquiterpenoid and phenylpropanoid classes in the essential oil from different Ocimum species. More number of predominant metabolites is listed from

mitochondrial function, and/or causing lipid peroxidation (Agus 2021). These specialized metabolites mainly exhibit hepatotoxicity as the reactive metabolites and ROS are formed during their metabolism in the liver (Zárybnický et al. 2018). Consequently, such specialized metabolites must be carefully utilized in various applications due to their acute or chronic adverse effects beyond a specific level. However, up to certain levels, these metabolites either in purified form or plant extracts as a bouquet of compounds, might be safe for human usage. Further, these plant-based natural molecules are recommended to be used in formulations and not in pure form. the most studied Ocimum species with the higher number of chemotypes, whereas less number of principal metabolites is listed from the least studied Ocimum species

\section{Strategies to improve the chemotypes in Ocimum species}

For many aromatic crops, genetic enhancement using various approaches aims to improve chemical composition, essential oil and herb yield. The classical breeding methods, along with biotechnological interventions, can facilitate such improvement in the yield and quality of essential oil in important and popular Ocimum species. This includes various approaches like metabolic engineering, transgenic, and in vitro culture techniques (Fig. 7), as further described. 


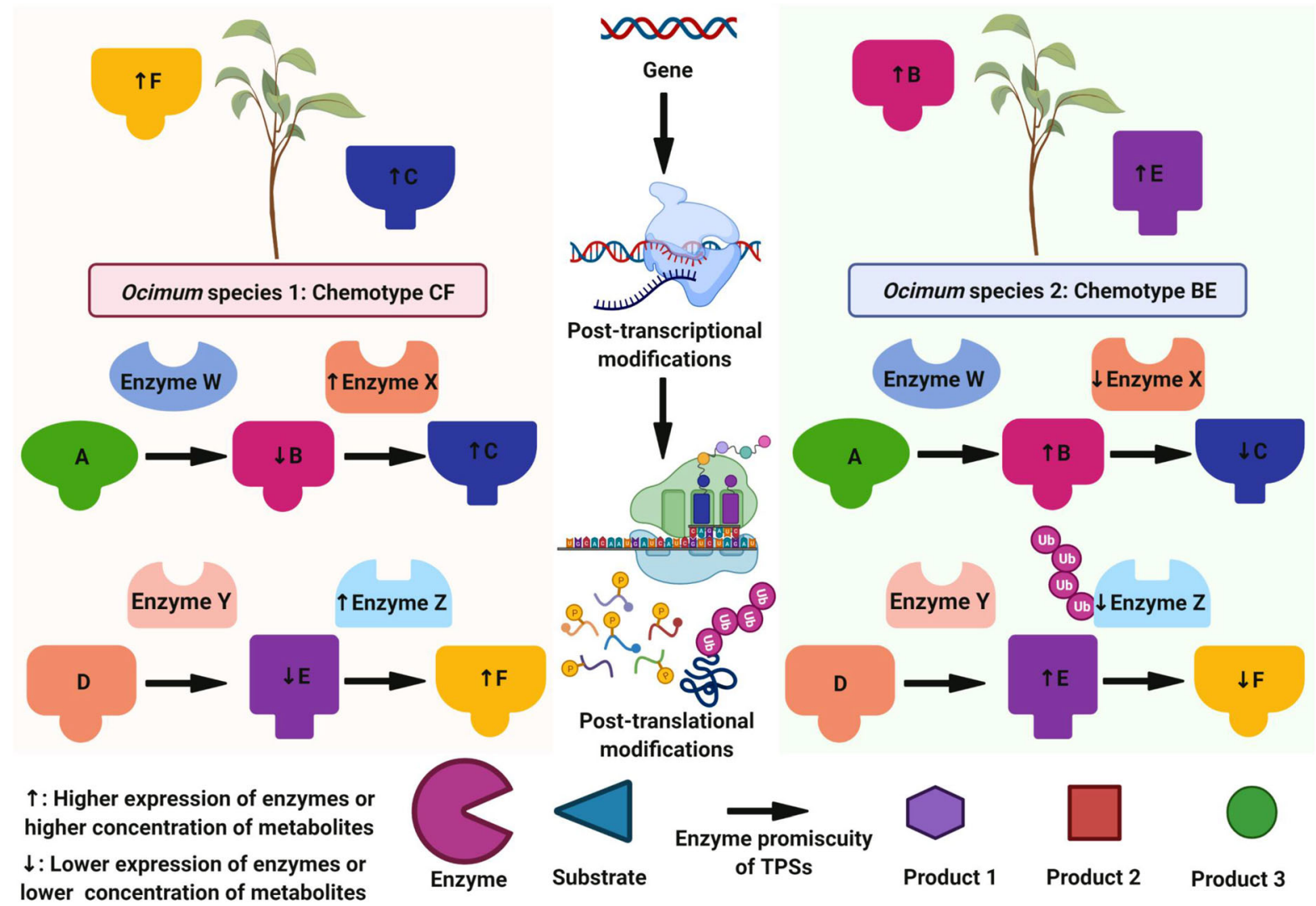

Fig. 5 Differential expression and regulation of genes involved in the biosynthesis of specialized metabolites at post-transcriptional and post-translational stages lead to the chemotypic variations in Ocimum species. Differential expression and regulation of various enzymes (represented by W, X, Y, and $\mathrm{Z}$, which are involved in the biosynthesis of specialized metabolites represented by B, C, E and F) of a representative pathway in Ocimum species 1 and Ocimum species 2 lead to the generation of different chemotypes such as $\mathrm{CF}$ and $\mathrm{BE}$, respectively. Higher expression of enzyme $\mathrm{X}$ and absence of

Breeding methods and polyploidy induction approach

Over the years, varieties of several Ocimum species with high essential oil yield and desired metabolite profiles have been developed through traditional breeding methods. For instance, high essential oil yielding, eugenol-rich O. tenuiflorum (CIM Ayu), methyl chavicol and linalool-rich O. basilicum (CIM Saumya), and $O$. basilicum with a flavor similar to Piper betle due to the presence of chavibetol have been developed (Lal et al. 2018). Also, morphologically similar but chemically distinct breeding lines of $O$. basilicum have been established, with eugenol (line ubiquitination of enzyme $\mathrm{Z}$ in Ocimum species 1 lead to higher levels of terminal metabolites $(\mathrm{C}$ and $\mathrm{F})$ and lower levels of intermediate metabolites (B and $\mathrm{E}$ ) of the pathway. In contrast, lower expression of enzyme $\mathrm{X}$ and ubiquitination of enzyme $\mathrm{Z}$ in Ocimum species 1 leads to lower levels of terminal metabolites ( $\mathrm{C}$ and $\mathrm{F}$ ) and higher levels of intermediate metabolites (B and E) of the pathway. Apart from this, TPSs contribute to the chemodiversity by catalyzing multiple product formation. This figure is created using BioRender.Com

SW) and methyl chavicol (line EMX-1), as the only phenylpropanoid components in their essential oil (Gang et al. 2001). Similarly, O. basilicum lines distinguished with camphor, methyl chavicol, and eugenol chemotypes have been developed with high essential oil content and herbage yield (Gupta 1994). The allelic basis behind the inheritance of such specialized metabolites has been discussed in a few studies (Dudai and Belanger 2016; Gupta 1994). Additionally, some breeding studies have focused on the development of $O$. basilicum varieties with improved agronomic traits, such as cold tolerance (Ribeiro and Simon 2007; Römer 2010) and disease resistance against basil Fusarium wilt (caused by 


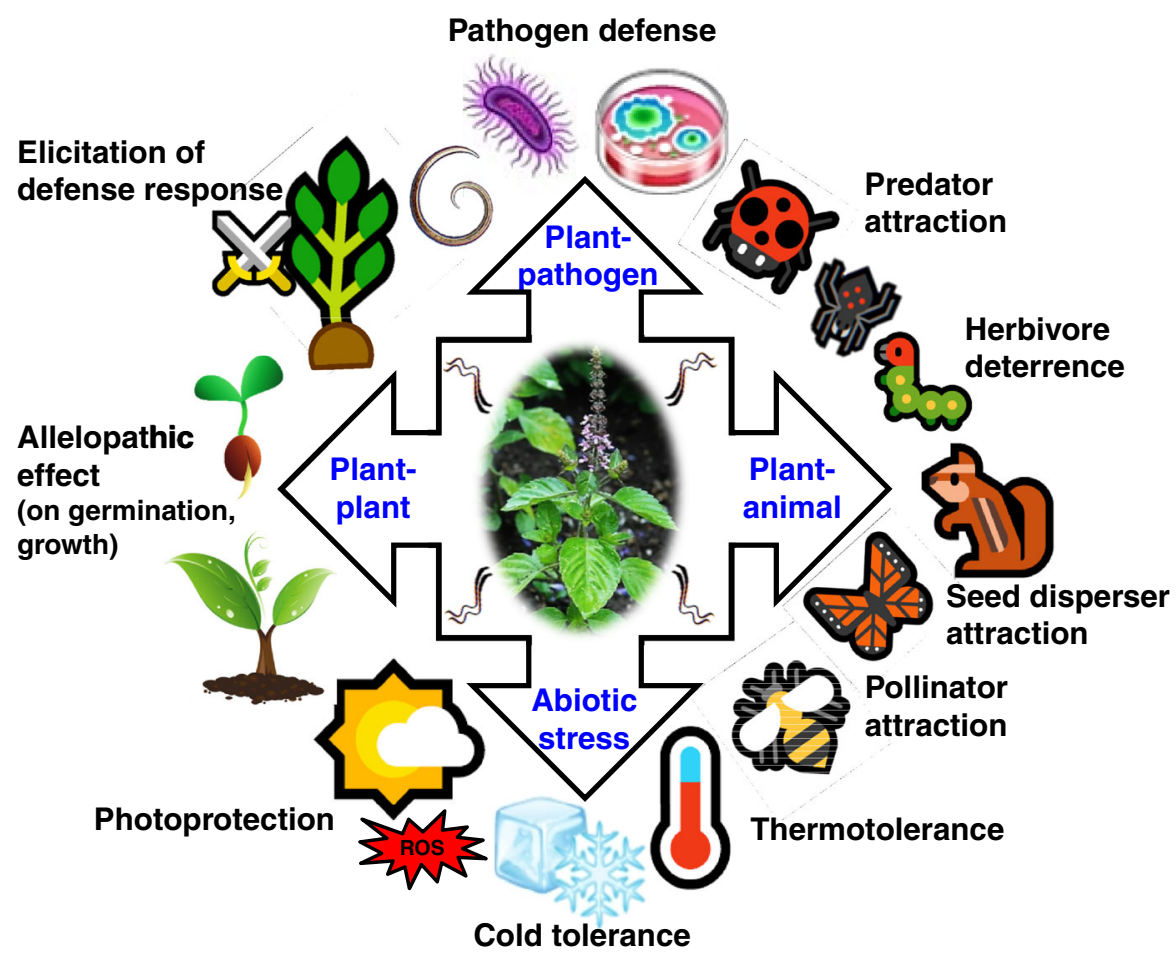

Fig. 6 The vital functions played by plant VOCs via plant-animal, plant-pathogen, plant-plant interactions with the surrounding environment, along with adaptation to various abiotic stress conditions. They perform a wide array of ecological functions, such as pollinator, seed disperser attraction, herbivore deterrence, pathogen defense, priming of defense response and allelopathic effect on the neighboring plant. They improve plant resistance to the variety of abiotic stress conditions via photoprotective, antioxidant, cold, and heat-tolerant action

Fusarium oxysporum) (Dudai et al. 2002) and downy mildew (Peronospora species) (Römer 2010). For ornamental purposes, $O$. basilicum lines with compact inflorescence have been generated (Dudai et al. 2002; Morales and Simon 1996). Interspecific hybridization can be employed to generate stable new varieties within the three to four generations (Dudai and Belanger 2016).

Earlier studies have indicated the effect of ploidy levels on essential oil production such that polyploid plants have significantly higher essential oil accumulation than diploid ones (Dhawan and Lavania 1996; Lavania 2005). The polyploidy induction approach by treating the seeds or other propagating material with colchicine has been used for decades in crop improvement programs. Omidbaigi et al. (2010) induced tetraploidy in $O$. basilicum by colchicine treatment to seeds and apical meristem of seedlings. This resulted in a $69 \%$ increment in the essential oil content in the tetraploid plant compared to the diploid.
Additionally, polyploidy was generated in an interspecific hybrid between eugenol-rich $O$. gratissimum and thymol-rich $O$. viride that could produce eugenol $(50-55 \%)$ and thymol (7-10\%). Further, their selfing and selection led to the development of two lines, one with $80-85 \%$ eugenol, while another with $82-85 \%$ thymol chemotypes (Khosla et al. 1990). Thus, interspecific hybridization and polyploidy generation offer additional ways for the targeted breeding to modulate chemotypes and essential oil yield.

Metabolic engineering through transgenic approaches

Metabolic engineering requires an in-depth understanding of the specialized biosynthetic pathways. To improve the yield and composition of some of the most valuable terpenoids and phenylpropanoids in the essential oil of specific Ocimum species, pathway engineering can be explored as a targeted approach 
(Fig. 8). The identification and functional characterization of genes entailed in the biosynthesis of specialized metabolites as chemotypes is crucial to manipulate any steps in their biosynthetic pathways through metabolic pathway engineering. Recently, key genes involved in the specialized metabolite biosynthesis have been characterized from different Ocimum species. These include 4-COUMARATECOA LIGASE (Ok4CL7 and Ok4CL15) (Lavhale et al. 2021) of the phenylpropanoid pathway, 3HYDROXY-3-METHYLGLUTARYL-COA REDUCTASE (OkHMGR) (Bansal et al. 2018) of the MVA pathway, and $\beta$-CARYOPHYLLENE SYNTHASE $(O k B C S)$, a sesquiterpenoid synthase (Jayaramaiah et al. 2016) characterized from $O$. kilimandscharicum. Also, several genes from $O$. basilicum have been characterized, such as PHENYLALANINE AMMONIA-LYASE (ObPAL) (Khakdan et al. 2018) of the phenylpropanoid pathway, 4-HYDROXYPHENYLPYRUVATE REDUCTASE (ObHPPR) and TYROSINE AMINOTRANSFERASE (ObTAT) involved in the rosmarinic acid biosynthesis (Li et al. 2019), OXIDOSQUALENE CYCLASES (OSCs) and cytochrome P450s (CyP450s) in the ursolic acid and oleanolic acid biosynthesis (Ghosh 2018). Anand et al. (2016) have characterized EUGENOL SYNTHASE $(E G S)$ involved in the phenylpropanoid biosynthesis from several Ocimum species. The metabolic engineering techniques can facilitate particular manipulation in metabolite flux to achieve higher levels of the desired metabolites (Dudareva et al. 2013; Lange and Ahkami 2013; Marchev et al. 2020). HMGR enzyme from the MVA pathway and 1-deoxy-D-xylulose-5phosphate synthase (DXS) and 1-deoxy-D-xylulose-5phosphate reductoisomerase (DXR) enzymes from the MEP pathway determine the metabolite flux for isoprenoid biosynthesis (Rodríguez-Concepción 2006). In the study conducted by Xie et al. (2008), higher activity of enzymes from the MEP pathway has been correlated well with the high level of citral in $O$. basilicum (line $\mathrm{SD}$ ). On the contrary, the high activity of PAL has been observed in O. basilicum (line EMX-1), which is rich in methyl chavicol. The transcriptomic, proteomic, and biochemical approaches have revealed the reduced carbon flux into the phenylpropanoid pathway resulting in the terpenoid-rich chemical profile of $O$. basilicum (line SD) (Xie et al. 2008). In a similar context, the higher level of terminal enzymes from the terpenoid biosynthetic pathways along with low levels of PAL could be attributed to the increased flux in the terpenoid biosynthesis (Iijima et al. 2004). Thus, directing carbon flux through the overexpression or silencing of critical enzymes from the entry, key intermediate or terminal points (Fig. 8) of either phenylpropanoid or terpenoid pathways will help to modify or improve the key chemotypes in Oсітиm species.

Many transgenic plant species have been developed that produce increased levels of monoterpenoids through overexpression of TPSs using the constitutively expressing promoters in heterologous system (Aharoni et al. 2003, 2006). Recently, overexpression of $H M G R$ from terpenoid-rich $O$. kilimandscharicum $(O k H M G R)$ in different phenylpropanoid-rich Ocimum species (O. basilicum, O. gratissimum, and O. tenuiflorum) has led to terpenoid accumulation with increased essential oil content (Bansal et al. 2018). Further, many enzymes of the metabolic pathway occur as isoforms. As PAL isoforms are localized in different subcellular sites, such as microsomal and cytosolic, it results in the differential subcellular distribution of cinnamic acid and, in turn, can partition phenylpropanoid biosynthesis into different end-product-specific pathways, such as flavonoids, lignin, etc. (Achnine et al. 2004). Also, different $4 \mathrm{CL}$ isoforms can regulate the flux of various hydroxycinnamic acids into other branches of phenylpropanoid biosynthesis (flavonoids, anthocyanins, phenylpropenes, lignins, coumarins, etc.) and thus, makes it a promising target for metabolic engineering in Ocimum species (Lavhale et al. 2018). For instance, the silencing of a specific 4CL isoform (OS4CL) through RNAi in $O$. tenuiflorum has led to a reduction in the eugenol level without affecting lignin and sinapic acid contents (Rastogi et al. 2013). Recently, characterization of two 4CL isoforms (Ok4CL7 and Ok4CL15) from $O$. kilimandscharicum have revealed that Ok4CL7 utilizes $p$-coumaric acid, ferulic acid and caffeic acid. In contrast, Ok4CL15 uses $p$-coumaric acid, ferulic acid and sinapic acid as substrates, indicating their potential role in lignin and phenylpropanoid biosynthesis (Lavhale et al. 2021). Overall, such reports have demonstrated that the desired change in the chemotypic profile can be achieved by targeting the specific isoform of the enzyme.

Furthermore, the transcription factors (TFs) play a pivotal role in regulating a specialized metabolic 


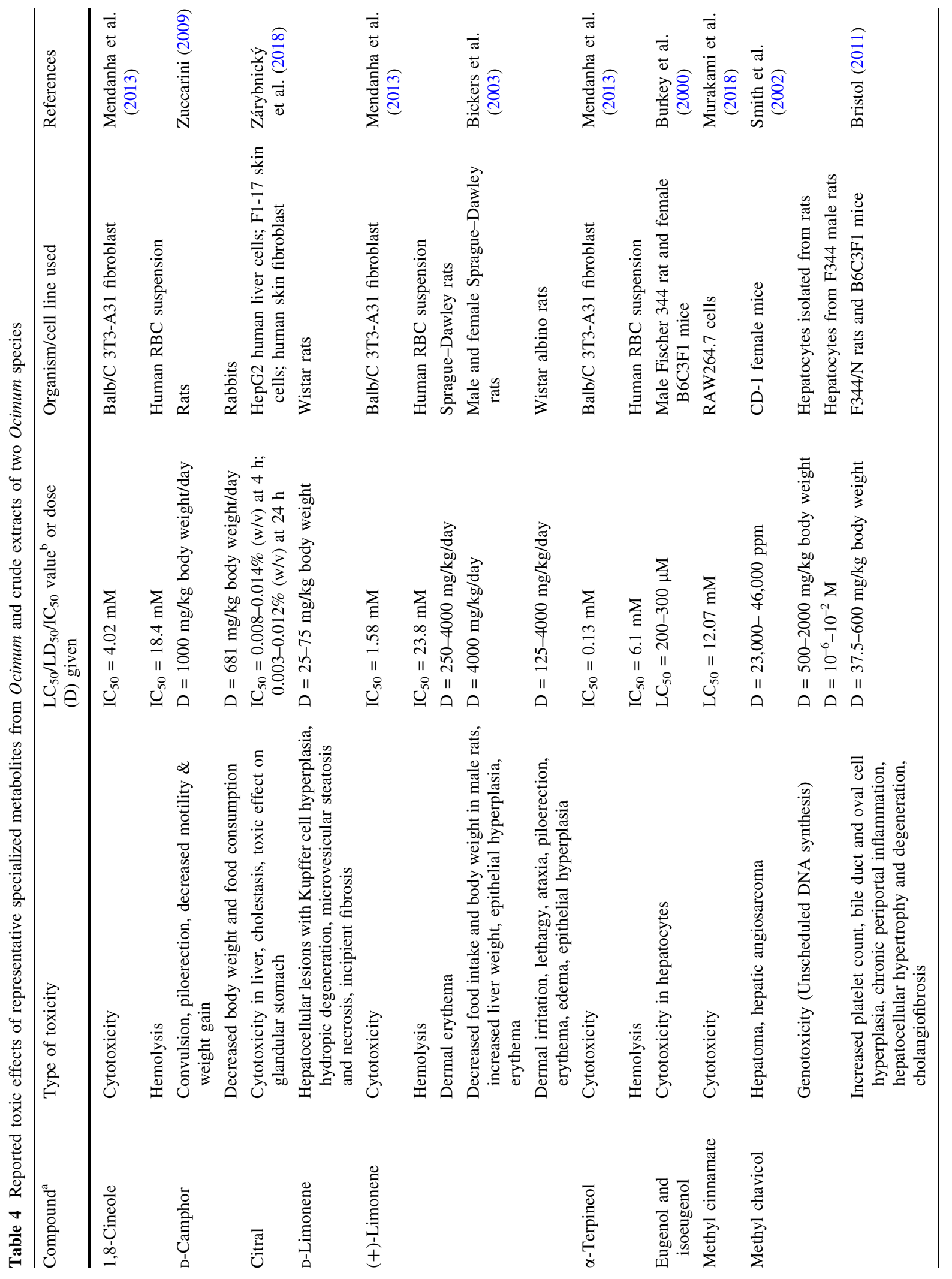




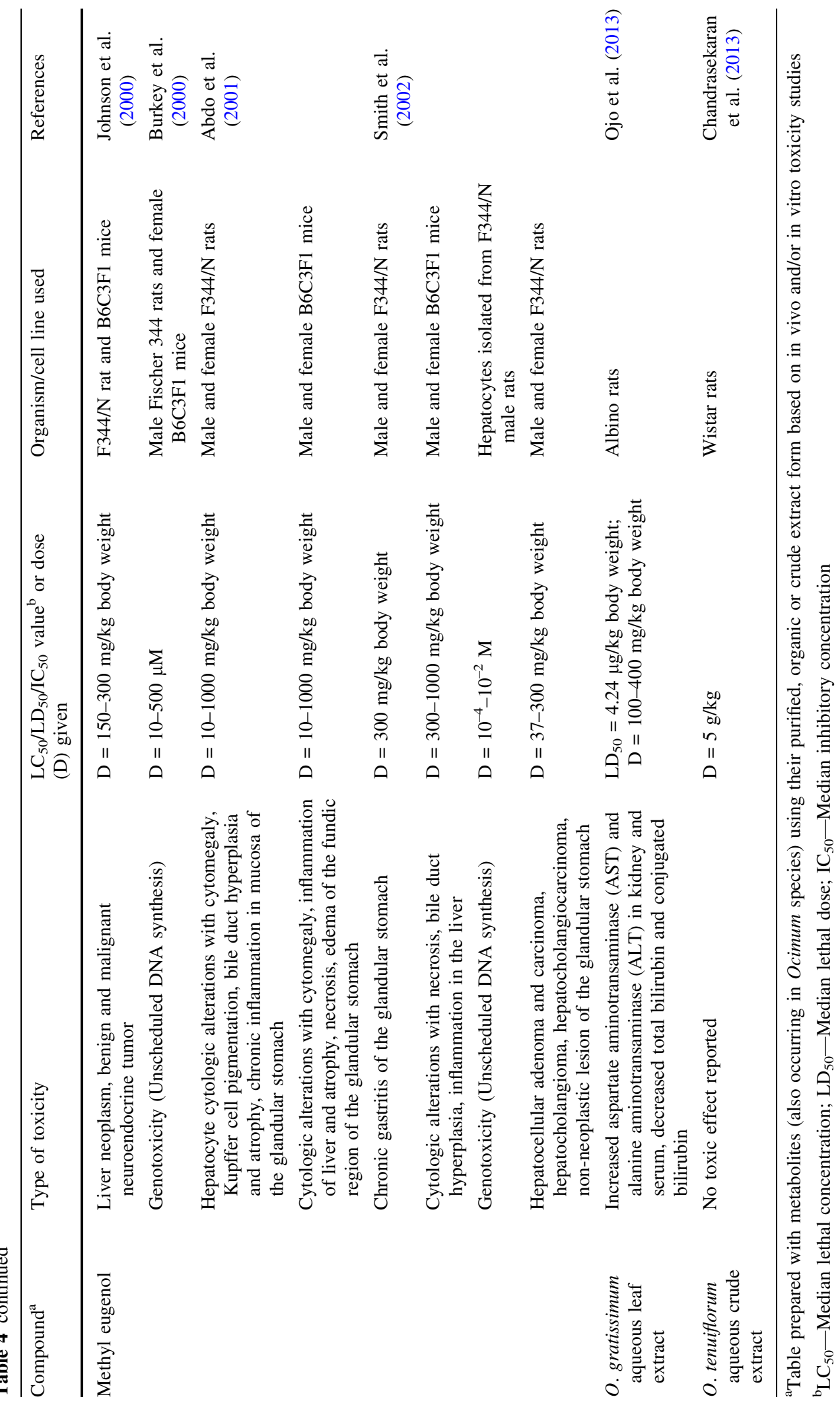




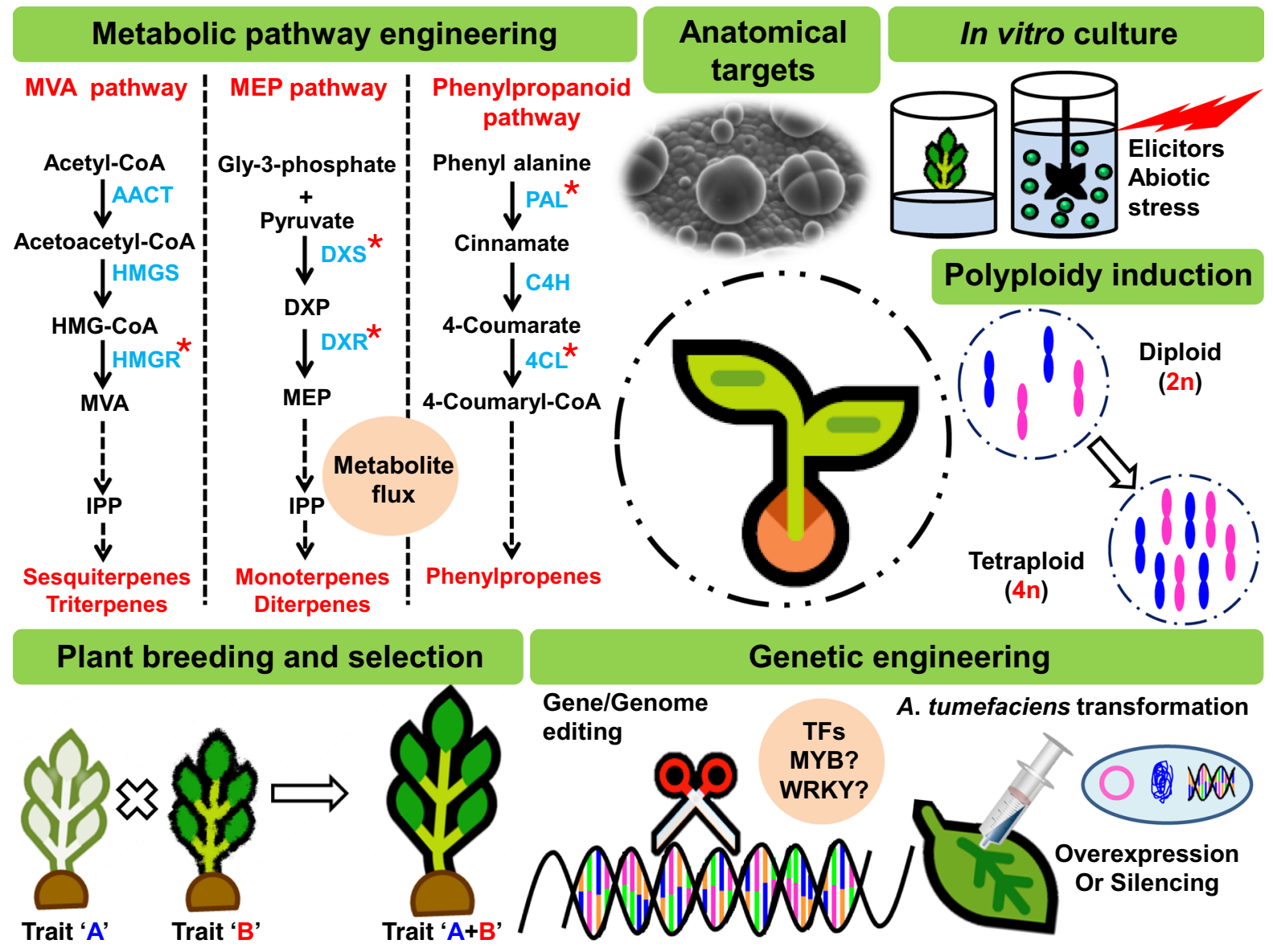

Fig. 7 Different strategies that can be employed for chemotype improvement in Ocimum species. This includes classical breeding methods and advanced biotechnological approaches, such as metabolic engineering, genome editing, transgenic, and in vitro culture approaches. *Indicates enzyme controlling metabolic flux and multi-steps indicated by dashed lines. AACT: Acetoacetyl-CoA thiolase; 4CL: 4-Coumarate-CoA ligase; C4H: trans-Cinnamate-4-hydroxylase; DXP: 1-Deoxy-

content by activating or repressing a set of the gene(s) in the chosen pathway (Grotewold 2008; Iwase et al. 2009). Over $40 \mathrm{TF}$ families such as $M Y B$, WRKY, bZIP, bHLH, HB, NAC, etc., have been discovered through transcriptome sequencing from $O$. basilicum and $O$. tenuiforum that are known regulators of the specialized metabolism in plants (Rastogi et al. 2014). Recently, Rastogi et al. (2020) have studied the expression patterns of TFs from the specialized metabolism to understand the regulation of terpenoid and phenylpropanoid biosynthesis. The
D-xylulose-5-phosphate; DXR: 1-Deoxy-D-xylulose-5-phosphate reductoisomerase; DXS: 1-Deoxy-D-xylulose-5-phosphate synthase; HMG-CoA: 3-Hydroxy-3-methylglutarylCoA; HMGR: 3-Hydroxy-3-methylglutaryl-CoA reductase; HMGS: 3-Hydroxy-3-methylglutaryl-CoA synthase; IPP: Isopentenyl pyrophosphate; MVA: Mevalonic acid; MEP: 2-C-Methyl-D-erythritol-4-phosphate; PAL: Phenylalanine ammonia-lyase

similarity observed among the expression patterns of bHLH1_25905, EREB, MADS box_50254, MYB3, MYB5, MYC, and TTGI TFs; and PAL, 4CL, and trans-cinnamate-4-hydroxylase $(\mathrm{C} 4 \mathrm{H})$ enzymes of phenylpropanoid pathway from three Ocimum species (O. gratissimum, O. kilimandscharicum, and O. tenuiflorum) have supported the hypothesis that regulation of gene(s) expression occurs through TFs binding to their respective promoters owing to broad structural and functional similarity (Rastogi et al. 2020). Moreover, $O$. basilicum plants ectopically expressing peltate glandular trichome-specific TFs MsYABBY5 
and $M s M Y B$ from $M$. spicata resulted in the reduced production of specialized metabolites, indicating their role as repressors (Reddy et al. 2017; Wang et al. 2016). Thus, metabolite flux analysis and interventions for suppressing the expression of TFs, which negatively impact the pathway, could also enhance the yields.

The recently discovered and Nobel-winning RNAguided genome editing technique, clustered regularly interspaced short palindromic repeats/CRISPR-associated 9 endonuclease (CRISPR/Cas9), is a potential tool for crop improvement owing to its high efficiency, simplicity, and specificity (Arora and Narula 2017).
Metabolic engineering by targeting multiple genes can be achieved through the multiplex CRISPR/Cas9 system to turn plants into bio-factories for specialized metabolite biosynthesis (Bhambhani et al. 2021; Karkute et al. 2017). Several genes that encode for the enzymes involved in the biosynthesis of many specialized metabolites are present in a cluster on the chromosomes, and the CRISPR/Cas9 tool has proven as an efficient method for knock-in or knock-out of gene clusters (Bhambhani et al. 2021). Plants with polyploidy show multiple homologs of the gene of interest can be targeted through sgRNA-based CRISPR/Cas9-mediated genome editing (Wilson

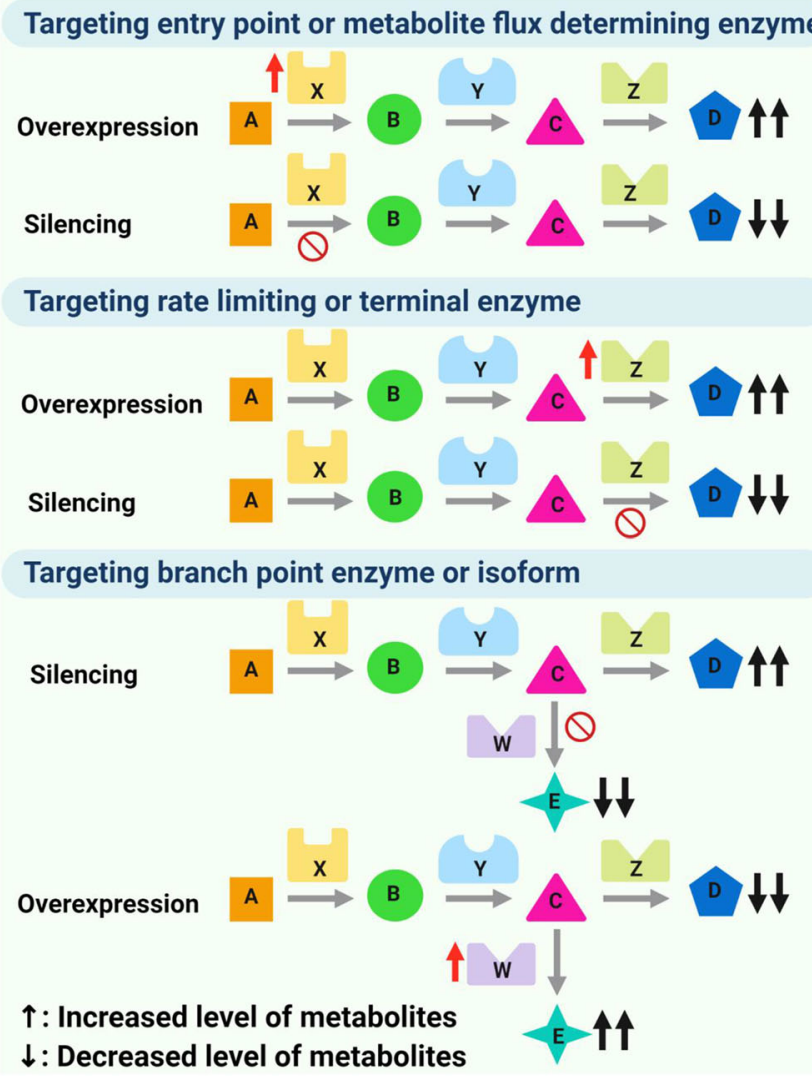

Fig. 8 Metabolic engineering approaches for manipulating the desired chemotype by either increasing or decreasing the levels of specific metabolites include overexpression or silencing of the enzyme(s) (represented by W, X, Y, and Z, which are involved in the biosynthesis of specialized metabolites represented by B, C, D and E) either at the entry point, important middle step(s), branch or terminal points in a specialized metabolic pathway. Metabolic engineering approaches for the overexpression of enzymes include target gene expression under constitutive promoter and CRISPRa for gene upregulation. In
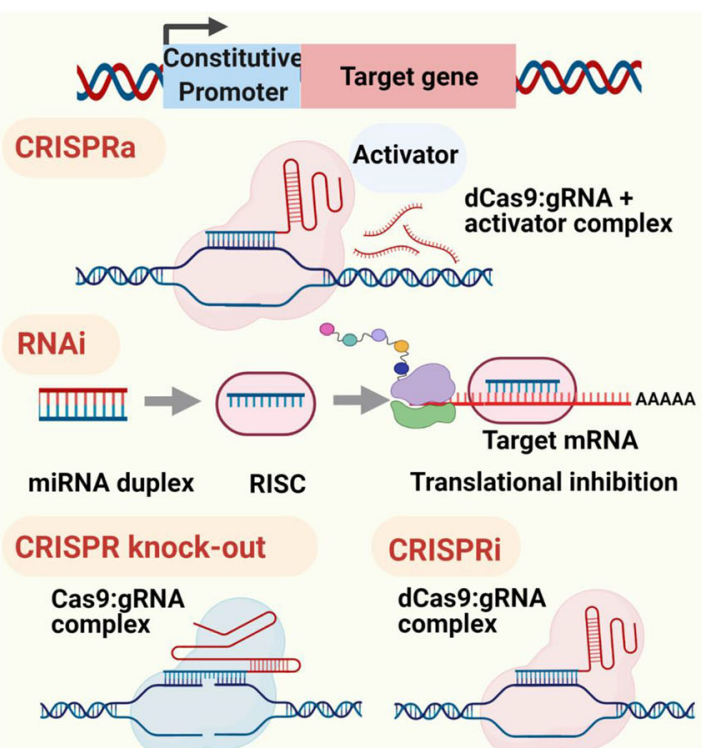

Translational inhibition
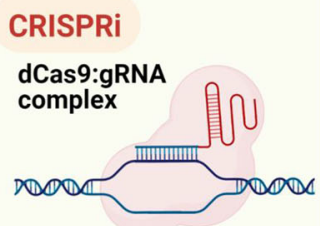

Transcriptional regulation

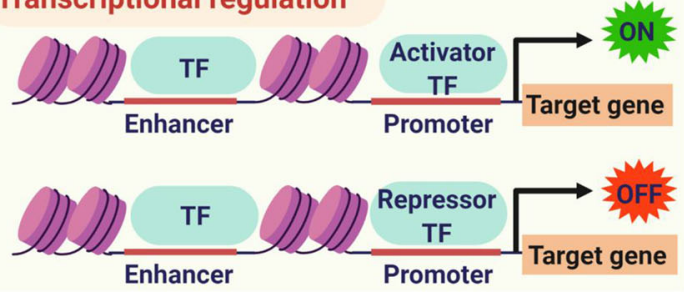

contrast, downregulation of enzymes in the pathway can be achieved through RNAi at the translational level, CRISPRi at the transcriptional level or CRISPR knock-out. Expression of TFs, which act as either positive or negative regulators of the pathway, can also be manipulated to achieve the desired level of chemotype in the chosen Ocimum species. CRISPRa: CRISPR activation, CRISPRi: CRISPR interference, dCas9: Nucleasedeactivated Cas9, gRNA: guide RNA, miRNA: micro RNA, RISC: RNA-induced silencing complex. This figure is created using BioRender.Com 
et al. 2019). Thus, a similar approach can be used in the Ocimum species where polyploidy is reported for enhancing desired metabolites. The CRISPR/Cas9 has been applied recently in metabolic engineering to produce specific metabolites (Fig. 8) in medicinal plants; for example, knocking out $4^{\prime}-O-M E T H Y L$ TRANSFERASE 2 (4'-OMT2) gene from the benzylisoquinoline alkaloid pathway has resulted in the reduced production of morphine, thebaine, etc. in Papaver somniferum (Alagoz et al. 2016). Also, the biosynthesis of diterpenoid tanshinones was blocked by targeting the diterpene synthase gene (SmCPS1) in the Chinese medicinal plant Salvia miltiorrhiza, which diverted geranylgeranyl pyrophosphate (GGPP) to taxol biosynthesis (Li et al. 2017). Recently, Navet and Tian (2020) have utilized CRISPR/Cas9 to generate downy mildew resistant lines in $O$. basilicum. The genome sequence of $O$. tenuiflorum (Upadhyay et al. 2015), O. gratissimum chloroplast genome sequence (Balaji et al. 2021), and different transcriptome sequences from O. basilicum, O. tenuiflorum (Rastogi et al. 2014), O. americanum (Zhan et al. 2016), O. gratissimum, and $O$. kilimandscharicum (Anand et al. 2019; Singh et al. 2020) are available. Consequently, such resource availability can boost the mass production of crucial chemotypes from the selected Ocimum species by targeting specific biosynthetic pathway genes through CRISPR/Cas9 technology or other genome editing approaches where sequence information is a prerequisite. Thus, CRISPR/Cas9 studies will have an enormous potential for chemotype improvement in these Ocimum species. Additionally, the integrative analysis using transcriptomic, proteomic, and metabolomic approaches will give a system-level framework for identifying crucial genes or pathways involved in the biosynthesis of specialized metabolites and their regulation, and subsequently, this may speed up the process of advancement in Ocimum species to improve the quality and yield of essential oil. Recently, the integration of transcriptomics with metabolomics has helped to discover the tissuespecific biosynthesis and compartmentalization of major metabolites, like camphor and eugenol in O. kilimandscharicum (Singh et al. 2020), which needs to be further explored.

The anatomical structures, where the essential oil (represents only the content of volatiles in the anatomical structures recovered by steam distillation) is biosynthesized and stored in Ocimum species, can be targeted to improve chemotype contents. The types of glandular trichome (peltate and capitate), their size and density can affect the net efficiency of essential oil accumulation (Maurya et al. 2019) as the level of secretion is relative to trichome size (Huchelmann et al. 2017) and density (Deschamps et al. 2006). The methyl chavicol accumulation pattern from $O$. basilicum leaf tissue correlated well with the peltate gland density and CVOMT expression in the peltate glands at different developmental stages (Deschamps et al. 2006). Recently, Maurya et al. (2019) have demonstrated that the essential oil content is dependent on the density and size of peltate and capitate glandular trichomes using microscopic analysis in different Ocimum species (O. basilicum, $O$. gratissimum, O. kilimandscharicum, and $O$. tenuiflorum). Subsequently, the high essential oil content in $O$. basilicum was associated with a larger size of peltate trichomes despite their low density compared to other Ocimum species (Maurya et al. 2019). Additionally, several TFs governing glandular trichome development have been identified (Huchelmann et al. 2017). For instance, Matías-Hernández et al. (2017) exhibited an increase in the trichome density along with increased artemisinin content when a MYB TF (AaMYB1) was overexpressed in Artemisia annua plant. Also, exogenous treatment of phytohormones (gibberellic acid and calliterpenone) in M. arvensis induced the formation of a greater number of trichomes with the increased diameter, which resulted in an increased essential oil accumulation with high menthol and menthone contents (Bose et al. 2013). Recently, transcriptomic analysis of $O$. basilicum and $O$. tenuiflorum was carried out to identify genes involved in the glandular trichome development concerning the essential oil biosynthesis. Most of the transcripts belonged to the TF families, such as $b H L H$, $C 2 H 2, R 2 R 3 M Y B$, and $R 3 M Y B$, which regulate trichome development. Their higher expression in $O$. basilicum than $O$. tenuiflorum may be associated with the high essential oil content of $O$. basilicum (Chandra et al. 2020). Thus, all such reports reveal that higher accumulation of essential oil can be facilitated by the large size and high density of trichomes. Moreover, the development of the glandular trichome is driven by a TF interactome network, which can either act as an activator or inhibitor (Lange and Turner 2013). Consequently, the characterization of 
such interactome to modulate anatomy and density of glandular trichomes in Ocimum species for the biosynthesis and storage of higher quantities of essential oil with important chemotypes would be a great biotechnological challenge in the future.

In vitro tissue-culture techniques for Ocimum species

Many Ocimum species have been successfully regenerated using in vitro propagation (Dode et al. 2003; Manan et al. 2016; Rady and Nazif 2005; Saha et al. 2010; Singh and Sehgal 1999). In addition to this, the use of elicitors in callus, cell, and organ cultures for the overproduction of the specialized metabolites is an effective strategy (Fig. 7) for chemotype improvement (Namdeo 2007). For example, the callus culture has been more influential in the production of betulinic acid than in vitro derived leaves from $O$. basilicum, O. kilimandscharicum, and O. tenuiflorum (Pandey et al. 2015). The light quality also has strongly influenced the phenylpropanoid biosynthesis (Nadeem et al. 2019; Nazir et al. 2020b), while exogenous melatonin is effective in phenolics production from the callus cultures of $O$. basilicum (Duran et al. 2019; Nazir et al. 2020a). Furthermore, differentiated plantlets or organ culture is beneficial for metabolite production with higher and stable essential oil yield (Karuppusamy 2009). Particularly, shoot culture has proven the best option for the higher accumulation of specialized metabolites than cultivated plants (Murthy et al. 2014). Methyl chavicol level was higher in the essential oil from the in vitro propagated $O$. basilicum than ex vitro and in vivo plants (Manan et al. 2016). Also, in vitro grown leaves and somatic embryos had higher quantities of eugenol than field-grown O. basilicum and O. tenuiflorum leaves (Bhuvaneshwari et al. 2016). However, cell culture can be superior for the production of metabolites with a higher yield by scaling up the cell culture (Nitzsche et al. 2004). Mathew and Sankar (2014) have reported higher total terpenoid content in cell culture in the presence of an elicitor than field-grown O. basilicum, O. gratissimum, and $O$. tenuiflorum plants. Similarly, leaf-derived suspension cultures accumulated 11-fold higher rosmarinic acid than callus cultures or leaves from the field-grown O. basilicum plants (Kintzios et al. 2003). With the treatment of elicitors and precursor feeder, the accumulation of total phenylpropanoids has been elevated in suspension cell cultures with correlated $P A L$ expression in $O$. tenuiflorum (Vyas and Mukhopadhyay 2018). Likewise, recently, higher triterpenoids (such as betulinic acid, ursolic acid, oleanolic acid, and rosmarinic acid) production has been achieved in the $O$. basilicum suspension culture (Pandey et al. 2019). In O. basilicum, high levels of nepetoidins have accumulated in callus and suspension cultures (Berim and Gang 2020). Subsequently, 2.7-fold high linalool and a 50\% rise in methyl chavicol have been observed with silver nitrate as an elicitor in cell suspension cultures from $O$. basilicum (Açıkgöz 2020).

The hairy roots induced by Agrobacterium rhizogenes mediated transformation are efficient for specialized metabolite production (Murthy et al. 2008). These are genetically stable and can grow in media devoid of growth regulators. They have a high growth rate and can produce particular metabolites from the plant's aerial part (Srivastava and Srivastava 2007). For instance, the enhanced levels of ursolic acid and eugenol in hairy root cultures of $O$. tenuiflorum have well corresponded with concentrations and duration of exposure of elicitors and the age of the cultures (Sharan et al. 2019). Biswas (2020) has shown the enhanced rosmarinic acid content using methyl jasmonate as an elicitor in the non-transformed O. basilicum root culture. Further, under both light and dark conditions, rosmarinic acid accumulation is higher in hairy root cultures from the green basil cultivar of $O$. basilicum than those of the purple basil cultivar (Kwon et al. 2021). Previously, elite hairy root lines have been developed with significantly higher rosmarinic acid levels than non-transformed roots of O. basilicum (Srivastava et al. 2016). In addition to this, somatic hybridization is used to produce hybrids from related species or distant genera (Grosser et al. 2000). Somaclonal variations can be helpful to enhance the essential oil profile of Ocimum species. These variations, if genetically stable for many generations, can be incorporated through plant breeding techniques (Krishna et al. 2016). Biotransformation is another approach that can be used to accumulate metabolites of particular stereospecificity and regioselectivity, utilizing cell or organ culture (Giri et al. 2001). 


\section{Conclusion and future perspectives}

Several chemotypes from different Ocimum species have been reported with a multitude of medicinal, culinary, and industrial applications. The approaches of classical breeding, interspecific hybridization, and tissue culture have been fruitful in increasing the total essential oil content as well as developing specific chemotypes in Ocimum species till now. Still, globally there is a high demand for naturally occurring specialized metabolites. Although several of such commercially important metabolites can be chemically produced, synthetic products are often left with racemic mixtures, while the natural compounds are free of such manufacturing defects and leftovers. It is important to understand adverse effects (if any) of these metabolites to fine tune the concentrations in the final products or define dose. Hence, to mitigate such market needs, the recent biotechnological interventions and synthetic biology tools have an outstanding potential for the chemotypic improvement of Ocimum species for their economic expansion. An enhanced chemotypic profile in Ocimum species could also improve other traits, such as tolerance to abiotic stresses, disease resistance to phytopathogens, pest control, an allelopathic effect for weed control and phytoremediation potential. The current genome editing tools will also help us to understand the biosynthetic pathways of specialized metabolites and provide an ideal option to improve essential oil yield and quality. However, the lack of whole genomic and transcriptomic sequences from important Ocimum species will be a challenge to exploit hidden chemopotential and chemotype advancements using genome editing tools. Further, identification and characterization of the TF networks regulating specialized biosynthetic pathways and correlating them with the metabolome will be necessary for effective TF manipulation in chemotype improvement. Nevertheless, comprehensive metabolomic profiling of various organs and organelles will bring more exciting information on fine-tuning of biosynthetic pathways for important specialized metabolites. Thus, extensive research aimed at the functional analysis of genes involved in the biosynthesis, regulation, and transport of specialized metabolites would be indispensable to enhance the market value of several Ocimum species and their chemotypes.
Acknowledgements TPG thanks University Grants Commission (New Delhi, India) for a research fellowship and the Academy of Scientific and Innovative Research (Uttar Pradesh, India) for the academic program of Ph.D. This work was supported by the Council of Scientific and Industrial Research (CSIR), New Delhi, Government of India as a CSIRNCL-IGIB Joint Research Initiative program under the XIIth five-year plan project (BSC0124).

Authors' contributions TPG: Conceptualization, investigation, formal analysis, visualization, writing-original draft preparation. BBD: conceptualization, visualization, methodology, writingreviewing and editing. APG: conceptualization, visualization, writing-reviewing and editing, supervision, funding acquisition.

Funding This work was supported by the Council of Scientific and Industrial Research, New Delhi, Government of India as a CSIR-NCL-IGIB Joint Research Initiative program under the XIIth five-year plan project (BSC0124).

Availability of data and material All data generated or analyzed during this study is included in this manuscript and its supplementary information files.

Code availability Not applicable.

\section{Declarations}

Conflicts of interest The authors declare that they have no conflict of interest.

Ethical approval Not applicable.

Consent to participate Not applicable.

Consent for publication Not applicable.

\section{References}

Abdo KM, Cunningham ML, Snell ML, Herbert RA, Travlos GS, Eldridge SR, Bucher JR (2001) 14-Week toxicity and cell proliferation of methyleugenol administered by gavage to F344 rats and $\mathrm{B} 6 \mathrm{C} 3 \mathrm{~F} 1$ mice. Food Chem Toxicol 39:303-316

Achnine L, Blancaflor EB, Rasmussen S, Dixon RA (2004) Colocalization of L-phenylalanine ammonia-lyase and cinnamate 4-hydroxylase for metabolic channeling in phenylpropanoid biosynthesis. Plant Cell 16:3098-3109

Açıkgöz MA (2020) Establishment of cell suspension cultures of Ocimum basilicum L. and enhanced production of pharmaceutical active ingredients. Ind Crops Prod 148:112278

Ademiluyi AO, Oyeleye SI, Oboh G (2016) Biological activities, antioxidant properties and phytoconstituents of essential oil from sweet basil (Ocimum basilicum L.) leaves. Comp Clin Path 25:169-176 
Agus HH (2021) Terpene toxicity and oxidative stress. In: Patel VB, Preedy VR (eds) Toxicology: oxidative stress and dietary antioxidants. Academic Press, Cambridge

Aharoni A, Giri AP, Deuerlein S, Griepink F, de Kogel WJ, Verstappen FW, Verhoeven HA, Jongsma MA, Schwab W, Bouwmeester HJ (2003) Terpenoid metabolism in wildtype and transgenic Arabidopsis plants. Plant Cell 15:2866-2884

Aharoni A, Jongsma MA, Kim TY, Ri MB, Giri AP, Verstappen FW, Schwab W, Bouwmeester HJ (2006) Metabolic engineering of terpenoid biosynthesis in plants. Phytochem Rev 5:49-58

Alagoz Y, Gurkok T, Zhang B, Unver T (2016) Manipulating the biosynthesis of bioactive compound alkaloids for nextgeneration metabolic engineering in opium poppy using CRISPR-Cas 9 genome editing technology. Sci Rep 6:30910

Ali HM, Nguta JM, Mapenay IO, Musila FM, Omambia VM, Matara DN (2021) Ethnopharmacological uses, biological activities, chemistry and toxicological aspects of Ocimum americanum var. americanum (Lamiaceae). J Phytopharmacol 10:56-60

Amaral-Baroli A, Lago JHG, de Almeida CV, de Almeida M, Scotti MT, Leone GF, Soares MG, Cavalari AA, Sartorelli P (2016) Variability in essential oil composition produced by micropropagated (in vitro), acclimated (ex vitro) and infield plants of Ocimum basilicum (Lamiaceae). Ind Crops Prod 86:180-185

Amor G, Sabbah M, Caputo L, Idbella M, De Feo V, Porta R, Fechtali T, Mauriello G (2021) Basil essential oil: composition, antimicrobial properties, and microencapsulation to produce active chitosan films for food packaging. Foods 10:121

Anand A, Jayaramaiah RH, Beedkar SD, Singh PA, Joshi RS, Mulani FA, Dholakia BB, Punekar SA, Gade WN, Thulasiram HV, Giri AP (2016) Comparative functional characterization of eugenol synthase from four different Ocimum species: implications on eugenol accumulation. Biochim Biophys Acta Proteins Proteom 1864:1539-1547

Anand A, Jayaramaiah RH, Beedkar SD, Dholakia BB, Lavhale SG, Punekar SA, Gade WN, Thulasiram HV, Giri AP (2019) Terpene profiling, transcriptome analysis and characterization of cis- $\beta$-terpineol synthase from Ocimum. Physiol Mol Biol Plants 25:47-57

Antić MP, Jelačić SC, Knudsen TMŠ (2019) Chemical composition of the essential oils of three Ocimum basilicum L. cultivars from Serbia. Not Bot Hortic Agrobot Cluj Napoca 47:347-351

Arora L, Narula A (2017) Gene editing and crop improvement using CRISPR-Cas9 system. Front Plant Sci 8:1932

Balaji R, Ravichandiran K, Tanuja A, Parani M (2021) The complete chloroplast genome of Ocimum gratissimum from India-a medicinal plant in the Lamiaceae. Mitochondrial DNA B Resour 6:948-950

Baldwin IT, Halitschke R, Paschold A, Von Dahl CC, Preston CA (2006) Volatile signaling in plant-plant interactions: "talking trees" in the genomics era. Science 311:812-815

Bansal S, Narnoliya LK, Mishra B, Chandra M, Yadav RK, Sangwan NS (2018) HMG-CoA reductase from Camphor Tulsi (Ocimum kilimandscharicum) regulated MVA dependent biosynthesis of diverse terpenoids in homologous and heterologous plant systems. Sci Rep 8:1-15

Batista MC, Fonseca MCM, Teodoro AV, Martins EF, Pallini A, Venzon M (2017) Basil (Ocimum basilicum L.) attracts and benefits the green lacewing Ceraeochrysa cubana Hagen. Biol Control 110:98-106

Benelli G, Pavela R, Maggi F, Wandjou JGN, Koné-Bamba D, Sagratini G, Vittori S, Caprioli G (2019) Insecticidal activity of the essential oil and polar extracts from Ocimum gratissimum grown in Ivory Coast: efficacy on insect pests and vectors and impact on non-target species. Ind Crops Prod 132:377-385

Berim A, Gang DR (2020) Extractability, stability, and accumulation of nepetoidins in Ocimum basilicum L. leaves and cell cultures. Plant Cell Tissue Organ Cult 143:75-85

Bhambhani S, Kondhare KR, Giri AP (2021) Advanced genome editing strategies for manipulation of plant specialized metabolites pertaining to biofortification. Phytochem Rev. https://doi.org/10.1007/s11101-021-09749-1

Bhavya ML, Obulaxmi S, Devi SS (2021) Efficacy of Ocimum tenuiflorum essential oil as grain protectant against coleopteran beetle, infesting stored pulses. J Food Sci Technol 58:1611-1616

Bhuvaneshwari K, Gokulanathan A, Jayanthi M, Govindasamy V, Milella L, Lee S, Yang DC, Girija S (2016) Can Ocimum basilicum L. and Ocimum tenuiflorum L. in vitro culture be a potential source of secondary metabolites? Food Chem 194:55-60

Bickers D, Calow P, Greim H, Hanifin JM, Rogers AE, Saurat JH, Sipes IG, Smith RL, Tagami H (2003) A toxicologic and dermatologic assessment of linalool and related esters when used as fragrance ingredients. Food Chem Toxicol 41:919-942

Biswas T (2020) Elicitor induced increased rosmarinic acid content of in vitro root cultures of Ocimum basilicum L. (Sweet Basil). Plant Sci Today 7:157-163

Bose SK, Yadav RK, Mishra S, Sangwan RS, Singh A, Mishra B, Srivastava A, Sangwan NS (2013) Effect of gibberellic acid and calliterpenone on plant growth attributes, trichomes, essential oil biosynthesis and pathway gene expression in differential manner in Mentha arvensis L. Plant Physiol Biochem 66:150-158

Bown D (2001) The herb society of America new herbs and their uses. DK, New York

Brilli F, Loreto F, Baccelli I (2019) Exploiting plant volatile organic compounds (VOCs) in agriculture to improve sustainable defense strategies and productivity of crops. Front Plant Sci 10:264

Bristol DW (2011) NTP 3-month toxicity studies of estragole (CAS No. 140-67-0) administered by gavage to F344/N rats and $\mathrm{B} 6 \mathrm{C} 3 \mathrm{~F} 1$ mice. Toxic Rep Ser 82:1-11

Burkey JL, Sauer JM, McQueen CA, Sipes IG (2000) Cytotoxicity and genotoxicity of methyleugenol and related congeners-a mechanism of activation for methyleugenol. Mutat Res Fundam Mol Mech 453:25-33

Carović-Stanko K, Liber Z, Besendorfer V, Javornik B, Bohanec B, Kolak I, Satovic Z (2010a) Genetic relations among basil taxa (Ocimum L.) based on molecular markers, nuclear DNA content, and chromosome number. Plant Syst Evol 285:13-22 
Carović-Stanko K, Orlić S, Politeo O, Strikić F, Kolak I, Milos M, Satovic Z (2010b) Composition and antibacterial activities of essential oils of seven Ocimum taxa. Food Chem 119:196-201

Carović-Stanko K, Liber Z, Politeo O, Strikić F, Kolak I, Milos M, Satovic Z (2011) Molecular and chemical characterization of the most widespread Ocimum species. Plant Syst Evol 294:253-262

Chandra M, Kushwaha S, Sangwan NS (2020) Comparative transcriptome analysis to identify putative genes related to trichome development in Ocimum species. Mol Biol Rep 47:6587-6598

Chandrasekaran CV, Srikanth HS, Anand MS, Allan JJ, Viji MH, Amit A (2013) Evaluation of the mutagenic potential and acute oral toxicity of standardized extract of Ocimum sanctum (OciBest ${ }^{\mathrm{TM}}$ ). Hum Exp Toxicol 32:992-1004

Choden D, Pokethitiyook P, Poolpak T, Kruatrachue M (2021) Phytoremediation of soil co-contaminated with zinc and crude oil using Ocimum gratissimum (L.) in association with Pseudomonas putida MU02. Int $\mathrm{J}$ Phytoremed 23:181-189

Chowdhary K, Kumar A, Sharma S, Pathak R, Jangir M (2018) Ocimum sp.: source of biorational pesticides. Ind Crops Prod 122:686-701

Cofer TM, Engelberth M, Engelberth J (2018) Green leaf volatiles protect maize (Zea mays) seedlings against damage from cold stress. Plant Cell Environ 41:1673-1682

Costa LCB, Pinto JEBP, Bertolucci SKV, Costa JCDB, Alves PB, Niculau EDS (2015) In vitro antifungal activity of Ocimum selloi essential oil and methylchavicol against phytopathogenic fungi. Rev Ciênc Agron 46:428-435

da Costa AS, Arrigoni-Blank MdF, Silva MAAPd, Alves MF, Santos DdA, Alves PB, Blank AF (2014) The impact of hybridization on the volatile and sensorial profile of $\mathrm{Oci}$ mum basilicum L. Sci World J. https://doi.org/10.1155/ 2014/824594

da Costa AS, Arrigoni-Blank MF, Blank AF, Silva MA, Pinto JA, Santos DA, Alves PB (2016) Volatile profile of basil cultivars and hybrids. Bol Latinoam Caribe Plantas Med Aromát 15:315-322

da Silva VD, Almeida-Souza F, Teles AM, Neto PA, MondegoOliveira R, Mendes Filho NE, Taniwaki NN, Abreu-Silva AL, da Silva Calabrese K, Mouchrek Filho VE (2018) Chemical composition of Ocimum canum Sims. essential oil and the antimicrobial, antiprotozoal and ultrastructural alterations it induces in Leishmania amazonensis promastigotes. Ind Crops Prod 119:201-208

Dada AO, Adekola FA, Odebunmi EO, Dada FE, Bello OM, Akinyemi BA, Bello OS, Umukoro OG (2020) Sustainable and low-cost Ocimum gratissimum for biosorption of indigo carmine dye: kinetics, isotherm, and thermodynamic studies. Int J Phytoremed 22:1524-1537

Dambolena JS, Zunino MP, López AG, Rubinstein HR, Zygadlo JA, Mwangi JW, Thoithi GN, Kibwage IO, Mwalukumbi JM, Kariuki ST (2010) Essential oils composition of Ocimum basilicum L. and Ocimum gratissimum L. from Kenya and their inhibitory effects on growth and fumonisin production by Fusarium verticillioides. Innov Food Sci Emerg Technol 11:410-414

Deschamps C, Gang D, Dudareva N, Simon JE (2006) Developmental regulation of phenylpropanoid biosynthesis in leaves and glandular trichomes of basil (Ocimum basilicum L.). Int J Plant Sci 167:447-454

Dhawan O, Lavania U (1996) Enhancing the productivity of secondary metabolites via induced polyploidy: a review. Euphytica 87:81-89

Dicke M, Baldwin IT (2010) The evolutionary context for herbivore-induced plant volatiles: beyond the 'cry for help.' Trends Plant Sci 15:167-175

Dicke M, van Loon JJ (2000) Multitrophic effects of herbivoreinduced plant volatiles in an evolutionary context. Entomol Exp Appl 97:237-249

Dode LB, Bobrowski VL, Braga EJB, Seixas FK, Schuch MW (2003) In vitro propagation of Ocimum basilicum L. (Lamiaceae). Acta Sci Biol Sci 25:435-437

Dudai N, Belanger FC (2016) Aroma as a factor in the breeding process of fresh herbs - the case of basil. In: HavkinFrenkel D, Dudai N (eds) Biotechnology in flavor production, 2nd edn. John Wiley and Sons, Oxford

Dudai N, Chaimovitsh D, Reuveni R, Ravid U, Larkov O, Putievsky E (2002) Breeding of sweet basil (Ocimum basilicum) resistant to Fusarium wilt caused by Fusarium oxysporum f. sp. basilicum. J Herbs Spices Med Plants 9:45-51

Dudareva N, Pichersky E (2000) Biochemical and molecular genetic aspects of floral scents. Plant Physiol 122:627-634

Dudareva N, Klempien A, Muhlemann JK, Kaplan I (2013) Biosynthesis, function and metabolic engineering of plant volatile organic compounds. New Phytol 198:16-32

Duran RE, Kilic S, Coskun Y (2019) Melatonin influence on in vitro callus induction and phenolic compound production in sweet basil (Ocimum basilicum L.). Vitro Cell Dev Biol Plant 55:468-475

El-Rokiek KG, Sed SA, El-Wakeel MA, Dawood MG, ElAwadi M (2018) Allelopathic effect of the two medicinal plants Plectranthus amboinicus (Lour.) and Ocimum basilicum L. on the growth of Pisum sativum L. and associated weeds. Middle East J Agric Res 7:1146-1153

Engelberth J, Alborn HT, Schmelz EA, Tumlinson JH (2004) Airborne signals prime plants against insect herbivore attack. Proc Natl Acad Sci 101:1781-1785

Farhang V, Amini J, Ebadollahi A, Sadeghi GR (2014) Ocimum basilicum L. essential oil cultivated in Iran: chemical composition and antifungal activity against three Phytophthora species. Arch Phytopathol Pflanzenschutz 47:1696-1703

Gang DR (2005) Evolution of flavors and scents. Annu Rev Plant Biol 56:301-325

Gang DR, Wang J, Dudareva N, Nam KH, Simon JE, Lewinsohn E, Pichersky E (2001) An investigation of the storage and biosynthesis of phenylpropenes in sweet basil. Plant Physiol 125:539-555

Ghosh S (2018) Triterpene functional genomics in Ocimum. In: Shasany A, Kole C (eds) The Ocimum genome. Compendium of plant genomes. Springer, Cham

Giri A, Dhingra V, Giri C, Singh A, Ward OP, Narasu ML (2001) Biotransformations using plant cells, organ cultures and enzyme systems: current trends and future prospects. Biotechnol Adv 19:175-199

Gonçalves S, Romano A (2013) In vitro culture of lavenders (Lavandula spp.) and the production of secondary metabolites. Biotechnol Adv 31:166-174 
Grayer RJ, Kite GC, Goldstone FJ, Bryan SE, Paton A, Putievsky E (1996) Infraspecific taxonomy and essential oil chemotypes in sweet basil, Ocimum basilicum. Phytochemistry 43:1033-1039

Grosser JW, Ollitrault P, Olivares-Fuster O (2000) Somatic hybridization in citrus: an effective tool to facilitate variety improvement. Vitro Cell Dev Biol Plant 36:434-449

Grotewold E (2008) Transcription factors for predictive plant metabolic engineering: Are we there yet? Curr Opin Biotechnol 19:138-144

Gupta S (1994) Genetic analysis of some chemotypes in Ocimum basilicum var. glabratum. Plant Breed 112:135-140

Gupte A, Karjikar M, Nair J (2012) Biosorption of copper using mucilaginous seeds of Ocimum basilicum. Acta Biol Indica $1: 113-119$

Gurav TP, Jayaramaiah RH, Punekar SA, Dholakia BB, Giri AP (2020) Generation of novelties in the genus Ocimum as a result of natural hybridization: a morphological, genetical and chemical appraisal. Ind Crops Prod 156:112859

Hassanpouraghdam MB, Hassani A, Shalamzari MS (2010) Menthone-and estragole-rich essential oil of cultivated Ocimum basilicum L. from Northwest Iran. Chemija 21:59-62

Holm Y, Hiltunen R (1999) Basil: the genus Ocimum. CRC Press, Amsterdam

Huchelmann A, Boutry M, Hachez C (2017) Plant glandular trichomes: natural cell factories of high biotechnological interest. Plant Physiol 175:6-22

Hüe T, Cauquil L, Fokou JH, Dongmo PJ, Bakarnga-Via I, Menut C (2015) Acaricidal activity of five essential oils of Ocimum species on Rhipicephalus (Boophilus) microplus larvae. Parasitol Res 114:91-99

Hzounda JBF, Jazet PMD, Lazar G, Răducanu D, Caraman I, Bassene E, Boyom FF, Lazar IM (2016) Spectral and chemometric analyses reveal antioxidant properties of essential oils from four Cameroonian Ocimum. Ind Crops Prod 80:101-108

Iijima Y, Davidovich-Rikanati R, Fridman E, Gang DR, Bar E, Lewinsohn E, Pichersky E (2004) The biochemical and molecular basis for the divergent patterns in the biosynthesis of terpenes and phenylpropenes in the peltate glands of three cultivars of basil. Plant Physiol 136:3724-3736

Iwase A, Matsui K, Ohme-Takagi M (2009) Manipulation of plant metabolic pathways by transcription factors. Plant Biotechnol J 26:29-38

Jacobowitz JR, Weng J-K (2020) Exploring uncharted territories of plant specialized metabolism in the postgenomic era. Annu Rev Plant Biol 71:631-658

Jayaramaiah RH, Anand A, Beedkar SD, Dholakia BB, Punekar SA, Kalunke RM, Gade WN, Thulasiram HV, Giri AP (2016) Functional characterization and transient expression manipulation of a new sesquiterpene synthase involved in $\beta$-caryophyllene accumulation in Ocimum. Biochem Biophys Res Commun 473:265-271

Jiang Y, Ye J, Li S, Niinemets Ü (2016) Regulation of floral terpenoid emission and biosynthesis in sweet basil (Ocimum basilicum). J Plant Growth Regul 35:921-935

Johnson JD, Ryan MJ, Toft JD, Graves SW, Hejtmancik MR, Cunningham ML, Herbert R, Abdo KM (2000) Two-year toxicity and carcinogenicity study of methyleugenol in
F344/N rats and B6C3F1 mice. J Agric Food Chem 48:3620-3632

Kantheti P, Rajitha I, Padma A (2020) Development of ecofriendly mosquito repellent printed textiles with synthesized Ocimum basilicum leaf dye extract. Int J Mosq Res 7:31-38

Karkute SG, Singh AK, Gupta OP, Singh PM, Singh B (2017) CRISPR/Cas9 mediated genome engineering for improvement of horticultural crops. Front Plant Sci 8:1635

Karuppusamy S (2009) A review on trends in production of secondary metabolites from higher plants by in vitro tissue, organ and cell cultures. J Med Plants Res 3:1222-1239

Kessler A, Baldwin IT (2002) Plant responses to insect herbivory: the emerging molecular analysis. Annu Rev Plant Biol 53:299-328

Khakdan F, Alizadeh H, Ranjbar M (2018) Molecular cloning, functional characterization and expression of a drought inducible phenylalanine ammonia-lyase gene (ObPAL) from Ocimum basilicum L. Plant Physiol Biochem 130:464-472

Khan RA (2018) Natural products chemistry: the emerging trends and prospective goals. Saudi Pharm J 26:739-753

Khosla M (1995) Study of inter-relationship, phylogeny and evolutionary tendencies in genus Ocimum. Ind $\mathrm{J}$ Genet 55:71-83

Khosla M, Bradu B, Gupta S (1990) Polyploidy breeding in Ocimum for evolving high yielding, better quality strains of essentail oil importance. In: Bhattacharyya SC, Sen N, Sethi KL (eds) Biosciences. Aspect Publishing Press, London

Kim J, Felton GW (2013) Priming of antiherbivore defensive responses in plants. Insect Sci 20:273-285

Kintzios S, Makri O, Panagiotopoulos E, Scapeti M (2003) In vitro rosmarinic acid accumulation in sweet basil (Ocimum basilicum L.). Biotechnol Lett 25:405-408

Kitchlu S, Bhadauria R, Ram G, Bindu K, Khajuria RK, Ahuja A (2013) Chemo-divergence in essential oil composition among thirty one core collections of Ocimum sanctum L. grown under sub-tropical region of Jammu. India Am J Plant Sci 4:302-308

Krishna H, Alizadeh M, Singh D, Singh U, Chauhan N, Eftekhari M, Sadh RK (2016) Somaclonal variations and their applications in horticultural crops improvement. 3 Biotech $6: 54$

Kumar A, Mishra P, Rodrigues V, Baskaran K, Verma RS, Padalia RC, Sundaresan V (2019) Delineation of Ocimum gratissimum L. complex combining morphological, molecular and essential oils analysis. Ind Crops Prod 139:111536

Kunwar G, Pande C, Tewari G, Bhatt S, Tripathi S (2018) Phytoremedial potential of a new chemotype of Ocimum kilimandscharicum Guerke from Kumaun Himalaya. J Essent Oil Bear Plants 21:623-639

Kwon DY, Kim YB, Kim JK, Park SU (2021) Production of rosmarinic acid and correlated gene expression in hairy root cultures of green and purple basil (Ocimum basilicum L.). Prep Biochem Biotechnol 51:35-43

Lakshmanraj L, Gurusamy A, Gobinath MB, Chandramohan R (2009) Studies on the biosorption of hexavalent chromium from aqueous solutions by using boiled mucilaginous seeds of Ocimum americanum. J Hazard Mater 169:1141-1145 
Lal R, Gupta P, Chanotiya C, Sarkar S (2018) Traditional plant breeding in Ocimum. In: Shasany A, Kole C (eds) The Ocimum genome. Compendium of Plant Genomes. Springer, Cham

Lange BM, Ahkami A (2013) Metabolic engineering of plant monoterpenes, sesquiterpenes and diterpenes-current status and future opportunities. Plant Biotechnol J 11:169-196

Lange BM, Turner GW (2013) Terpenoid biosynthesis in trichomes-current status and future opportunities. Plant Biotechnol J 11:2-22

Lavania U (2005) Genomic and ploidy manipulation for enhanced production of phyto-pharmaceuticals. Plant Genet Resour 3:170-177

Lavhale SG, Kalunke RM, Giri AP (2018) Structural, functional and evolutionary diversity of 4-coumarate-CoA ligase in plants. Planta 248:1063-1078

Lavhale SG, Joshi RS, Kumar Y, Giri AP (2021) Functional insights into two Ocimum kilimandscharicum 4-coumarate-CoA ligases involved in phenylpropanoid biosynthesis. Int J Biol Macromol 181:202-210

Lawal OA, Ogunwande IA, Omikorede OE, Owolabi MS, Olorunsola FF, Sanni AA, Amisu KO, Opoku AR (2014) Chemical composition and antimicrobial activity of essential oil of Ocimum kilimandscharicum (R. Br.) Guerke: a new chemotype. Am J Essent Oils Nat Prod 2:41-46

Li QX, Chang CL (2016) Basil (Ocimum basilicum L.) oils. In: Preedy VR (ed) Essential oils in food preservation, flavor and safety. Academic Press, Cambridge, MA

Li B, Cantino PD, Olmstead RG, Bramley GL, Xiang C-L, Ma Z-H, Tan Y-H, Zhang D-X (2016) A large-scale chloroplast phylogeny of the Lamiaceae sheds new light on its subfamilial classification. Sci Rep 6:1-18

Li B, Cui G, Shen G, Zhan Z, Huang L, Chen J, Qi X (2017) Targeted mutagenesis in the medicinal plant Salvia miltiorrhiza. Sci Rep 7:43320

Li X, Kim JK, Park SU (2019) Molecular cloning and characterization of rosmarinic acid biosynthetic genes and rosmarinic acid accumulation in Ocimum basilicum L. Saudi J Biol Sci 26:469-472

Liu J, Osbourn A, Ma P (2015) MYB transcription factors as regulators of phenylpropanoid metabolism in plants. Mol Plant 8:689-708

Lodhi BA, Hussain MA, Ashraf MU, Haseeb MT, Muhammad G, Farid-ul-Haq M, Naeem-ul-Hassan M (2020) Basil (Ocimum basilicum $\mathrm{L}$.) seeds engender a smart material for intelligent drug delivery: on-off switching and real-time swelling, in vivo transit detection, and mechanistic studies. Ind Crops Prod 155:112780

Loreto F, Schnitzler JP (2010) Abiotic stresses and induced BVOCs. Trends Plant Sci 15:154-166

Loreto F, Velikova V (2001) Isoprene produced by leaves protects the photosynthetic apparatus against ozone damage, quenches ozone products, and reduces lipid peroxidation of cellular membranes. Plant Physiol 127:1781-1787

Lung I, Soran ML, Opriş O, Truşcă MRC, Niinemets Ü, Copolovici L (2016) Induction of stress volatiles and changes in essential oil content and composition upon microwave exposure in the aromatic plant Ocimum basilicum. Sci Total Environ 569:489-495
Manan AA, Taha RM, Mubarak EE, Elias H (2016) In vitro flowering, glandular trichomes ultrastructure, and essential oil accumulation in micropropagated Ocimum basilicum L. Vitro Cell Dev Biol Plant 52:303-314

Mandoulakani BA, Eyvazpour E, Ghadimzadeh M (2017) The effect of drought stress on the expression of key genes involved in the biosynthesis of phenylpropanoids and essential oil components in basil (Ocimum basilicum L.). Phytochemistry 139:1-7

Manikandan DB, Arumugam M, Veeran S, Sridhar A, Sekar RK, Perumalsamy B, Ramasamy T (2021a) Biofabrication of ecofriendly copper oxide nanoparticles using Ocimum americanum aqueous leaf extract: analysis of in vitro antibacterial, anticancer, and photocatalytic activities. Environ Sci Pollut Res 6:1-5

Manikandan DB, Sridhar A, Sekar RK, Perumalsamy B, Veeran S, Arumugam M, Karuppaiah P, Ramasamy T (2021b) Green fabrication, characterization of silver nanoparticles using aqueous leaf extract of Ocimum americanum (Hoary Basil) and investigation of its in vitro antibacterial, antioxidant, anticancer and photocatalytic reduction. J Environ Chem Eng 9:104845

Marchev AS, Yordanova ZP, Georgiev MI (2020) Green (cell) factories for advanced production of plant secondary metabolites. Crit Rev Biotechnol 40:443-458

Mathew R, Sankar PD (2014) Comparison of major secondary metabolites quantified in elicited cell cultures, non-elicited cell cultures, callus cultures and field grown plants of Ocimum. Int J Pharm Pharm Sci 6:102-106

Matías-Hernández L, Jiang W, Yang K, Tang K, Brodelius PE, Pelaz S (2017) AaMYB1 and its orthologue AtMYB61 affect terpene metabolism and trichome development in Artemisia annua and Arabidopsis thaliana. Plant J 90:520-534

Matondo A, Kilembe JT, Ngoyi EM, Kabengele CN, Kasiama GN, Lengbiye EM, Mbadiko CM, Inkoto CL, Bongo GN, Gbolo BZ, Falanga CM (2021) Oleanolic acid, ursolic acid and apigenin from Ocimum basilicum as potential inhibitors of the SARS-CoV-2 main protease: A molecular docking study. Int J Pathog Res 6:1-16

Maurya S, Sangwan NS (2019) Profiling of essential oil constituents in Ocimum Species. Proc Natl Acad Sci India Sect B Biol Sci 26:1-7

Maurya S, Chandra M, Yadav RK, Narnoliya LK, Sangwan RS, Bansal S, Sandhu P, Singh U, Kumar D, Sangwan NS (2019) Interspecies comparative features of trichomes in Ocimum reveal insights for biosynthesis of specialized essential oil metabolites. Protoplasma 256:893-907

Melo JS, D'souza SF (2004) Removal of chromium by mucilaginous seeds of Ocimum basilicum. Bioresour Technol 92:151-155

Mendanha SA, Moura SS, Anjos JL, Valadares MC, Alonso A (2013) Toxicity of terpenes on fibroblast cells compared to their hemolytic potential and increase in erythrocyte membrane fluidity. Toxicol in Vitro 27:323-329

Meyers M (2003) Basil: an herb society of America guide. The Herb Society of America, Kirtland

Mith H, Yayi-Ladékan E, Sika Kpoviessi SD, Yaou Bokossa I, Moudachirou M, Daube G, Clinquart A (2016) Chemical composition and antimicrobial activity of essential oils of Ocimum basilicum, Ocimum canum and Ocimum 
gratissimum in function of harvesting time. J Essent Oil Bear Plants 19:1413-1425

Moghaddam M, Alymanesh MR, Mehdizadeh L, Mirzaei H, Pirbalouti AG (2014) Chemical composition and antibacterial activity of essential oil of Ocimum ciliatum, as a new source of methyl chavicol, against ten phytopathogens. Ind Crops Prod 59:144-148

Mohammadi L, Ramezanian A, Tanaka F, Tanaka F (2021) Impact of Aloe vera gel coating enriched with basil (Ocimum basilicum $\mathrm{L}$.) essential oil on postharvest quality of strawberry fruit. Food Meas 15:353-362

Mondello L, Zappia G, Cotroneo A, Bonaccorsi I, Chowdhury JU, Yusuf M, Dugo G (2002) Studies on the essential oilbearing plants of Bangladesh. Part VIII. Composition of some Ocimum oils $O$. basilicum L. var. purpurascens; $O$. sanctum L. green; $O$. sanctum L. purple; O. americanum L., citral type; O. americanum L., camphor type. Flavour Fragr J 17:335-340

Morales MR, Simon JE (1996) New basil selections with compact inflorescences for the ornamental market. In: Janick J (ed) Progress in new crops. ASHS Press, Alexandria

Mosaddeghi MR, Pajoum Shariati F, Vaziri Yazdi SA, Nabi Bidhendi G (2020) Application of response surface methodology (RSM) for optimizing coagulation process of paper recycling wastewater using Ocimum basilicum. Environ Technol 41:100-108

Murakami Y, Kawata A, Suzuki S, Fujisawa S (2018) Cytotoxicity and pro-/anti-inflammatory properties of cinnamates, acrylates and methacrylates against RAW264.7 cells. Vivo 32:1309-1322

Murthy HN, Dijkstra C, Anthony P, White DA, Davey MR, Power JB, Hahn EJ, Paek KY (2008) Establishment of Withania somnifera hairy root cultures for the production of withanolide A. J Integr Plant Biol 50:975-981

Murthy HN, Lee E-J, Paek K-Y (2014) Production of secondary metabolites from cell and organ cultures: strategies and approaches for biomass improvement and metabolite accumulation. Plant Cell Tissue Organ Cult 118:1-16

Nadeem M, Abbasi BH, Younas M, Ahmad W, Zahir A, Hano C (2019) LED-enhanced biosynthesis of biologically active ingredients in callus cultures of Ocimum basilicum. J Photochem Photobiol B 190:172-178

Namdeo A (2007) Plant cell elicitation for production of secondary metabolites: a review. Pharmacogn Rev 1:69-79

Navet N, Tian M (2020) Efficient targeted mutagenesis in allotetraploid sweet basil by CRISPR/Cas9. Plant Direct 4:e00233

Nazir M, Ullah MA, Mumtaz S, Siddiquah A, Shah M, Drouet S, Hano C, Abbasi BH (2020a) Interactive effect of melatonin and UV-C on phenylpropanoid metabolite production and antioxidant potential in callus cultures of purple basil (Ocimum basilicum L. var. purpurascens). Molecules 25:1072

Nazir M, Ullah MA, Younas M, Siddiquah A, Shah M, GiglioliGuivarc'h N, Hano C, Abbasi BH (2020b) Light-mediated biosynthesis of phenylpropanoid metabolites and antioxidant potential in callus cultures of purple basil (Ocimum basilicum L. var purpurascens). Plant Cell Tissue Organ Cult 142:107-120
Nitzsche A, Tokalov SV, Gutzeit HO, Ludwig-Müller J (2004) Chemical and biological characterization of cinnamic acid derivatives from cell cultures of lavender (Lavandula officinalis) induced by stress and jasmonic acid. J Agric Food Chem 52:2915-2923

Occhipinti A, Capuzzo A, Bossi S, Milanesi C, Maffei ME (2013) Comparative analysis of supercritical $\mathrm{CO}_{2}$ extracts and essential oils from an Ocimum basilicum chemotype particularly rich in T-cadinol. J Essent Oil Res 25:272-277

Ojo OA, Oloyede OI, Olarewaju OI, Ojo AB, Ajiboye BO, Onikanni SA (2013) Toxicity studies of the crude aqueous leaves extracts of Ocimum gratissimum in albino rats. IOSR J Environ Sci Toxicol Food Technol 6:34-39

Olugbade T, Kolipha-Kamara M, Elusiyan C, Onawunmi G, Ogundaini A (2017) Essential oil chemotypes of three Ocimum species found in Sierra Leone and Nigeria. Med Aromat Plants 6:284

Omidbaigi R, Mirzaei M, Moghadam MS (2010) Difference of growth traits, essential oil content and compositions between diploid and induced tetraploid plants of basil (Ocimum basilicum L.). J Essent Oil Bear Pl 13:579-587

Oxenham SK, Svoboda KP, Walters DR (2005) Antifungal activity of the essential oil of basil (Ocimum basilicum). J Phytopathol 153:174-180

Padalia RC, Verma RS (2011) Comparative volatile oil composition of four Ocimum species from northern India. Nat Prod Res 25:569-575

Padalia RC, Verma RS, Chauhan A (2017) Diurnal variations in aroma profile of Ocimum basilicum L., O. gratissimum L., $O$. americanum L., and $O$. kilimandscharicum Guerke. J Essent Oil Res 29:248-261

Pandey AK, Singh P, Tripathi NN (2014) Chemistry and bioactivities of essential oils of some Ocimum species: an overview. Asian Pac J Trop Biomed 4:682-694

Pandey H, Pandey P, Singh S, Gupta R, Banerjee S (2015) Production of anti-cancer triterpene (betulinic acid) from callus cultures of different Ocimum species and its elicitation. Protoplasma 252:647-655

Pandey P, Singh S, Banerjee S (2019) Ocimum basilicum suspension culture as resource for bioactive triterpenoids: yield enrichment by elicitation and bioreactor cultivation. Plant Cell Tissue Organ Cult 137:65-75

Piras A, Gonçalves MJ, Alves J, Falconieri D, Porcedda S, Maxia A, Salgueiro L (2018) Ocimum tenuiflorum L. and Ocimum basilicum L., two spices of Lamiaceae family with bioactive essential oils. Ind Crops Prod 113:89-97

Piva RC, Verdan MH, Santos MD, Batistote M, Cardoso CA (2021) Manufacturing and characterization of craft beers with leaves from Ocimum selloi Benth. J Food Sci Technol 3:1-8

Purushothaman B, Prasannasrinivasan R, Suganthi P, Ranganathan B, Gimbun J, Shanmugam K (2018) A comprehensive review on Ocimum basilicum. J Nat Remedies 18:71-85

Quintana-Rodriguez E, Rivera-Macias LE, Adame-Alvarez RM, Torres JM, Heil M (2018) Shared weapons in fungusfungus and fungus-plant interactions? Volatile organic compounds of plant or fungal origin exert direct antifungal activity in vitro. Fungal Ecol 33:115-121 
Rady MR, Nazif NM (2005) Rosmarinic acid content and RAPD analysis of in vitro regenerated basil (Ocimum americanum) plants. Fitoterapia 76:525-533

Raguso RA, Pichersky E (1995) Floral volatiles from Clarkia breweri and C. concinna (Onagraceae): Recent evolution of floral scent and moth pollination. Plant Syst Evol 194:55-67

Raina AP, Gupta V (2018) Chemotypic characterization of diversity in essential oil composition of Ocimum species and varieties from India. J Essent Oil Res 30:444-456

Raina AP, Misra R (2018) Chemo-divergence in essential oil composition among germplasm collection of five Ocimum species from eastern coastal plains of India. J Essent Oil Res 30:47-55

Raina AP, Kumar A, Dutta M (2013) Chemical characterization of aroma compounds in essential oil isolated from "Holy Basil" (Ocimum tenuiflorum L.) grown in India. Genet Resour Crop Evol 60:1727-1735

Ramírez-Sandoval M, Melchor-Partida GN, Muñiz-Hernández S, Girón-Pérez MI, Rojas-García AE, Medina-Díaz IM, Robledo-Marenco ML, Velázquez-Fernández JB (2011) Phytoremediatory effect and growth of two species of Ocimum in endosulfan polluted soil. J Hazard Mater 192:388-392

Rana VS, Blazquez MA (2015) Essential oil composition of the aerial parts of five Ocimum species from Western India. J Essent Oil Bear Pl 18:1234-1241

Rao BRR, Kothari SK, Rajput DK, Patel RP, Darokar MP (2011) Chemical and biological diversity in fourteen selections of four Ocimum species. Nat Prod Commun 6:1705-1710

Rastogi S, Kumar R, Chanotiya CS, Shanker K, Gupta MM, Nagegowda DA, Shasany AK (2013) 4-Coumarate: CoA ligase partitions metabolites for eugenol biosynthesis. Plant Cell Physiol 54:1238-1252

Rastogi S, Meena S, Bhattacharya A, Ghosh S, Shukla RK, Sangwan NS, Lal RK, Gupta MM, Lavania UC, Gupta V (2014) De novo sequencing and comparative analysis of holy and sweet basil transcriptomes. BMC Genom 15:588

Rastogi S, Shah S, Kumar R, Vashisth D, Akhtar MQ, Kumar A, Dwivedi UN, Shasany AK (2019) Ocimum metabolomics in response to abiotic stresses: cold, flood, drought and salinity. PLoS ONE 14:e0210903

Rastogi S, Shah S, Kumar R, Kumar A, Shasany AK (2020) Comparative temporal metabolomics studies to investigate interspecies variation in three Ocimum species. Sci Rep 10:1-15

Rawat R, Tiwari V, Singh R, Bisht I (2017) Assessment of the essential oil composition in Ocimum species of Uttarakhand. J Essent Oil Bear Plants 20:1331-1341

Reddy VA, Wang Q, Dhar N, Kumar N, Venkatesh PN, Rajan C, Panicker D, Sridhar V, Mao HZ, Sarojam R (2017) Spearmint R2R3-MYB transcription factor $M s M Y B$ negatively regulates monoterpene production and suppresses the expression of geranyl diphosphate synthase large subunit (MsGPPS.LSU). Plant Biotechnol J 15:1105-1119

Rehman R, Hanif MA, Mushtaq Z, Mochona B, Qi X (2016) Biosynthetic factories of essential oils: the aromatic plants. Nat Prod Chem Res 4:277
Ribeiro P, Simon JE (2007) Breeding sweet basil for chilling tolerance. In: Janick J, Whipkey A (eds) Issues in new crops and new uses. ASHS Press, Alexandria

Rodríguez-Concepción M (2006) Early steps in isoprenoid biosynthesis: multilevel regulation of the supply of common precursors in plant cells. Phytochem Rev 5:1-15

Rohini B, Ishwarya SP, Rajasekharan R, Vijayakumar AK (2020) Ocimum basilicum seed mucilage reinforced with montmorillonite for preparation of bionanocomposite film for food packaging applications. Polym Test 87:106465

Romagni JG, Allen SN, Dayan FE (2000) Allelopathic effects of volatile cineoles on two weedy plant species. J Chem Ecol 26:303-313

Römer P (2010) Selection of basil (Ocimum basilicum L.) breeding material with improved tolerance to low temperature. Z Arznei Gewürzpflanzen 15:178-181

Rubiyanto D, Sastrohamidjojo H, Anwar C (2015) Complete chemo type of three species of basils (Ocimum basilicum) grown in Indonesia. J Essent Oil Bear Plants 18:982-991

Saha S, Dey T, Ghosh P (2010) Micropropagation of Ocimum kilimandscharicum Guerke (Labiatae). Acta Biol Crac Ser Bot 52:50-58

Santana ACM, Pereira GS, Boaventura CM, Uetenabaro APT, Costa LCB, Oliveira RA (2014) Rupture of glandular trichomes in Ocimum gratissimum leaves influences the content of essential oil during the drying method. Rev Bras Farmacogn 24:524-530

Santos ED, Leitão MM, Ito CN, Silva-Filho SE, Arena AC, de Souza Silva-Comar FM, Cuman RK, Oliveira RJ, Formagio AS, Kassuya CA (2021) Analgesic and anti-inflammatory articular effects of essential oil and camphor isolated from Ocimum kilimandscharicum Gürke leaves. J Ethnopharmacol 269:113697

Saran PL, Tripathy V, Saha A, Kalariya KA, Suthar MK, Kumar J (2017) Selection of superior Ocimum sanctum L. accessions for industrial application. Ind Crops Prod 108:700-707

Selvi MT, Thirugnanasampandan R, Sundarammal S (2015) Antioxidant and cytotoxic activities of essential oil of Ocimum canum Sims. from India. J Saudi Chem Soc 19:97-100

Shamsnejati S, Chaibakhsh N, Pendashteh AR, Hayeripour S (2015) Mucilaginous seed of Ocimum basilicum as a natural coagulant for textile wastewater treatment. Ind Crops Prod 69:40-47

Sharan S, Sarin N, Mukhopadhyay K (2019) Elicitor-mediated enhanced accumulation of ursolic acid and eugenol in hairy root cultures of Ocimum tenuiflorum L. is age, dose, and duration dependent. S Afr J Bot 124:199-210

Shiojiri K, Maeda T, Arimura GI, Ozawa R, Shimoda T, Takabayashi J (2002) Functions of plant infochemicals in tritrophic interactions between plants, herbivores and carnivorous natural enemies. Japanese J Appl Entomol Zool 46:117-133

Simon JE, Quinn J, Murray RG (1990) Basil: a source of essential oils. In: Janick J, Simon JE (eds) Advances in new crops. Timber Press, Portland

Singh D, Chaudhuri PK (2018) A review on phytochemical and pharmacological properties of Holy basil (Ocimum sanctum L.). Ind Crops Prod 118:367-382 
Singh NK, Sehgal C (1999) Micropropagation of 'Holy Basil'(Ocimum sanctum L.) from young inflorescences of mature plants. Plant Growth Regul 29:161-166

Singh SK, Anand A, Verma SK, Siddiqui M, Mathur A, Saklani $S$ (2011) Analysis of phytochemical and antioxidant potential of Ocimum kilimandscharicum Linn. Int J Curr Pharm Res 3:40-46

Singh S, Tewari G, Pande C, Singh C (2013) Variation in essential oil composition of Ocimum americanum L. from north-western Himalayan region. J Essent Oil Res 25:278-290

Singh P, Jayaramaiah RH, Sarate P, Thulasiram HV, Kulkarni MJ, Giri AP (2014) Insecticidal potential of defense metabolites from Ocimum kilimandscharicum against Helicoverpa armigera. PLoS ONE 9:e104377

Singh P, Kalunke RM, Giri AP (2015) Towards comprehension of complex chemical evolution and diversification of terpene and phenylpropanoid pathways in Ocimum species. RSC Adv 5:106886-106904

Singh P, Jayaramaiah RH, Agawane SB, Vannuruswamy G, Korwar AM, Anand A, Dhaygude VS, Shaikh ML, Joshi RS, Boppana R, Kulkarni MJ, Thulasiram HV, Giri AP (2016) Potential dual role of eugenol in inhibiting advanced glycation end products in diabetes: proteomic and mechanistic insights. Sci Rep 6:1-13

Singh P, Kalunke RM, Shukla A, Tzfadia O, Thulasiram HV, Giri AP (2020) Biosynthesis and tissue-specific partitioning of camphor and eugenol in Ocimum kilimandscharicum. Phytochemistry 177:112451

Smith RL, Adams TB, Doull J, Feron VJ, Goodman JI, Marnett LJ, Portoghese PS, Waddell WJ, Wagner BM, Rogers AE, Caldwell J, Sipes IG (2002) Safety assessment of allylalkoxybenzene derivatives used as flavouring substances-methyl eugenol and estragole. Food Chem Toxicol 40:851-870

Song B, Tang G, Sang X, Zhang J, Yao Y, Wiggins N (2013) Intercropping with aromatic plants hindered the occurrence of Aphis citricola in an apple orchard system by shifting predator-prey abundances. Biocontrol Sci Technol 23:381-395

Srivastava S, Srivastava AK (2007) Hairy root culture for massproduction of high-value secondary metabolites. Crit Rev Biotechnol 27:29-43

Srivastava S, Conlan XA, Adholeya A, Cahill DM (2016) Elite hairy roots of Ocimum basilicum as a new source of rosmarinic acid and antioxidants. Plant Cell Tissue Organ Cult 126:19-32

Suddee S, Paton A, Parnell J (2005) Taxonomic revision of tribe Ocimeae Dumort. (Lamiaceae) in continental South East Asia III. Ociminae. Kew Bull 60:3-75

Tucker AO, DeBaggio T (2000) The big book of herbs: a comprehensive illustrated reference to herbs of flavor and fragrance. Interweave Press, Loveland

Upadhyay AK, Chacko AR, Gandhimathi A, Ghosh P, Harini K, Joseph AP, Joshi AG, Karpe SD, Kaushik S, Kuravadi N, Lingu CS (2015) Genome sequencing of herb Tulsi (Ocimum tenuiflorum) unravels key genes behind its strong medicinal properties. BMC Plant Biol 15:212

Varga F, Carović-Stanko K, Ristić M, Grdiša M, Liber Z, Šatović Z (2017) Morphological and biochemical intraspecific characterization of Ocimum basilicum L. Ind Crops Prod 109:611-618

Verma RS, Padalia RC, Chauhan A, Thul ST (2013) Exploring compositional diversity in the essential oils of 34 Ocimum taxa from Indian flora. Ind Crops Prod 45:7-19

Verma RS, Kumar A, Mishra P, Kuppusamy B, Padalia RC, Sundaresan V (2016) Essential oil composition of four Ocimum spp. from the Peninsular India. J Essent Oil Res 28:35-41

Vieira RF, Simon JE (2006) Chemical characterization of basil (Ocimum spp.) based on volatile oils. Flavour Fragr J 21:214-221

Viña A, Murillo E (2003) Essential oil composition from twelve varieties of basil (Ocimum spp) grown in Colombia. J Braz Chem Soc 14:744-749

Vivaldo G, Masi E, Taiti C, Caldarelli G, Mancuso S (2017) The network of plants volatile organic compounds. Sci Rep $7: 1-18$

Vranová E, Coman D, Gruissem W (2013) Network analysis of the MVA and MEP pathways for isoprenoid synthesis. Annu Rev Plant Biol 64:665-700

Vyas P, Mukhopadhyay K (2018) Elicitation of phenylpropanoids and expression analysis of PAL gene in suspension cell culture of Ocimum tenuiflorum L. Proc Natl Acad Sci India Sect B Biol Sci 88:1207-1217

Wang Q, Reddy VA, Panicker D, Mao HZ, Kumar N, Rajan C, Venkatesh PN, Chua NH, Sarojam R (2016) Metabolic engineering of terpene biosynthesis in plants using a trichome-specific transcription factor MsYABBY5 from spearmint (Mentha spicata). Plant Biotechnol J 14:1619-1632

Werker E, Putievsky E, Ravid U, Dudai N, Katzir I (1993) Glandular hairs and essential oil in developing leaves of Ocimum basilicum L. (Lamiaceae). Ann Bot 71:43-50

Wilson FM, Harrison K, Armitage AD, Simkin AJ, Harrison RJ (2019) CRISPR/Cas9-mediated mutagenesis of phytoene desaturase in diploid and octoploid strawberry. Plant Methods 15:45

Xie Z, Kapteyn J, Gang DR (2008) A systems biology investigation of the MEP/terpenoid and shikimate/phenylpropanoid pathways points to multiple levels of metabolic control in sweet basil glandular trichomes. Plant $\mathrm{J}$ 54:349-361

Yarou BB, Bawin T, Boullis A, Heukin S, Lognay G, Verheggen FJ, Francis F (2018) Oviposition deterrent activity of basil plants and their essentials oils against Tuta absoluta (Lepidoptera: Gelechiidae). Environ Sci Pollut Res 25:29880-29888

Yarou BB, Bokonon-Ganta AH, Verheggen FJ, Lognay GC, Francis F (2020) Aphid behavior on Amaranthus hybridus L. (Amaranthaceae) associated with Ocimum spp. (Lamiaceae) as repellent plants. Agronomy 10:736

Yayi E, Moudachirou M, Chalchat JC (2001) Chemotyping of three Ocimum species from Benin: O. basilicum, O. canum and $O$. gratissimum. J Essent Oil Res 13:13-17

Zárybnický T, Boušová I, Ambrož M, Skálová L (2018) Hepatotoxicity of monoterpenes and sesquiterpenes. Arch Toxicol 92:1-3

Zhan X, Yang L, Wang D, Zhu JK, Lang Z (2016) De novo assembly and analysis of the transcriptome of Ocimum 
americanum var. pilosum under cold stress. BMC Genom 17:209

Zhou F, Pichersky E (2020) More is better: the diversity of terpene metabolism in plants. Curr Opin Plant Biol 55:1-10

Zoghbi MGB, Oliveira J, Andrade EHA, Trigo JR, Fonseca RCM, Rocha AES (2007) Variation in volatiles of Ocimum campechianum Mill. and Ocimum gratissimum L. cultivated in the North of Brazil. J Essent Oil Bear Plants 10:229-240

Zuccarini P (2009) Camphor: risks and benefits of a widely used natural product. J Appl Sci Environ Manag 13:69-74
Technavio (2019) Global basil essential oil market 2019-2023. https://www.technavio.com/report/global-basil-essentialoil-market-industry-analysis. Accessed 12 Oct 2020

WFO (2021) World Flora Online. http://www.worldfloraonline. org Accessed 23 Mar 2021

Publisher's Note Springer Nature remains neutral with regard to jurisdictional claims in published maps and institutional affiliations. 